\title{
31. PETROGRAPHY AND MINERAL COMPOSITIONS OF GABBROS RECOVERED IN DEEP SEA DRILLING PROJECT HOLE 453 ON THE WESTERN SIDE OF THE MARIANA TROUGH ${ }^{1}$
}

\author{
James H. Natland, Deep Sea Drilling Project, Scripps Institution of Oceanography, La Jolla, California
}

\begin{abstract}
The compositions, mineralogies, and textures of gabbros recovered in polymict breccias in Hole 453 indicate that they are the cumulus assemblages of calc-alkalic crystal fractionation that occurred beneath the West Mariana Ridge. They are among a class of gabbros known only from other calc-alkalic associations (e.g., the Lesser Antilles and the Peninsular Ranges batholith of Southern California) and differ from gabbros of stratiform complexes, ophiolites, and the ocean crust. Particularly abundant in the Hole 453 breccias are olivine-bearing gabbros with extremely calcic plagioclase $\left(\mathrm{An}_{94-97}\right)$ but with fairly iron-rich olivines $\left(\mathrm{Fo}_{76-77}\right)$. Other gabbros contain biotite and amphibole and occur in breccias with fairly high-grade greenschist facies (amphibole-chlorite-stilpnomelane) metabasalts. One unusual gabbro has experienced almost complete subsolidus recrystallization to an assemblage of aluminous magnesio-hornblende, anorthite, and green hercynitic spinel. This reaction, the extremely calcic plagioclase, the occurrence of biotite and amphibole, and the association with greenschist facies metamorphic rocks suggest that crystallization of the gabbros occurred at elevated $P\left(\mathrm{H}_{2} \mathrm{O}\right)$. Comparisons with other calc-alkalic gabbro suites suggest pressures in excess of 4 kbar (about $12 \mathrm{~km}$ depth). The gabbros were exposed by the early stages of opening of the Mariana Trough and imply that considerable uplift may have attended rifting. They were also subjected to hydrothermal alteration after breccia formation, resulting in formation of chlorite, epidote, actinolite, and prehnite. Temperatures of at least $200^{\circ} \mathrm{C}-$ and probably $350^{\circ} \mathrm{C}$-were reached, and most likely could not have been attained without extrusion or intrusion of magmas nearby, even though no such rocks were cored.
\end{abstract}

\section{INTRODUCTION}

One of the major surprises of Deep Sea Drilling Project Leg 60 was the recovery of gabbros in a complex polymict breccia in Hole 453 on the western side of the Mariana Trough (Fig. 1). Also in the breccias are metamorphosed calc-alkalic basalts, andesites, and dacites (Wood et al., this volume). The breccias were subjected to intense hydrothermal alteration after their formation, with temperatures locally exceeding $200^{\circ} \mathrm{C}$ (Lawrence and Natland, this volume). This caused significant changes in the chemistry and mineralogy of the rocks (Sharaskin, this volume).

The objective of this chapter is to explore the petrologic significance of the gabbros with respect to magmatic processes. For this purpose, I make use of the chemical data of Wood et al. (this volume) and some of the data of Sharaskin (this volume) and Bougault et al. (this volume). Mainly, however, the discussion will focus on mineral analyses determined by electron microprobe, in the context of the whole-rock chemical data. The metamorphic history of the gabbros and associated rocks is complex, involving an early stage of greenschist facies metamorphism, retrograde prehnite-pumpellyite facies metamorphism before the breccias were formed, and hydrothermal metamorphism after they were formed. Apart from petrographic information, consideration of the effects of metamorphism on primary rock chemistry, and some data on metamorphic minerals, the details of metamorphism will not be discussed here. I will, however, describe subsolidus reactions that occurred in a few gabbros.

\footnotetext{
1 Initial Reports of the Deep Sea Driling Project, Volume 60.
}

The mineralogical study was initiated because the chemistry of the gabbros suggested that they may have crystallized under conditions of elevated water pressure and because they were associated with calc-alkalic metavolcanic rocks derived from the West Mariana Ridge. Unmetamorphosed calc-alkalic lavas were drilled at Site 451 on the summit of the West Mariana Ridge about 44 $\mathrm{km}$ to the west of Site 453 during Leg 59 (Kroenke et al., 1980; Mattey et al., 1980). The gabbros therefore seemed likely to shed light on the processes of calc-alkalic differentiation on the West Mariana Ridge.

\section{SETTING}

From airgun profiles, the breccias appear to be flatlying and about 400 meters thick. They occur in a narrow, steep-walled, north-trending basin near the western side of the Mariana Trough (Fig. 1, inset). They are overlain by 455.5 meters of turbiditic vitric tuffs, the oldest of which are early Pliocene (approx. 5.0 m.y. old; see Site 453 chapter, this volume; Bleil, this volume; Ellis, this volume).

\section{LITHOLOGY}

A summary lithology of the Hole 453 breccias is shown on Fig. 2. The diagram also summarizes the proportions of clasts of different composition in each core and the proportions of clasts to breccia matrix. Three lithologic sequences were cored: (1) Cores 49-58, 85.5 meters of gabbro-metabasalt polymict breccia; (2) Cores 59-62, 28.5 meters of metavolcanic polymict breccia; and (3) Core 63, sheared, altered mafic gabbro of which 1.5 meters were recovered. One additional core brought up only material that had fallen down the hole.

A full description of these cores is presented in the Site 453 chapter (this volume), and detailed rock-by- 

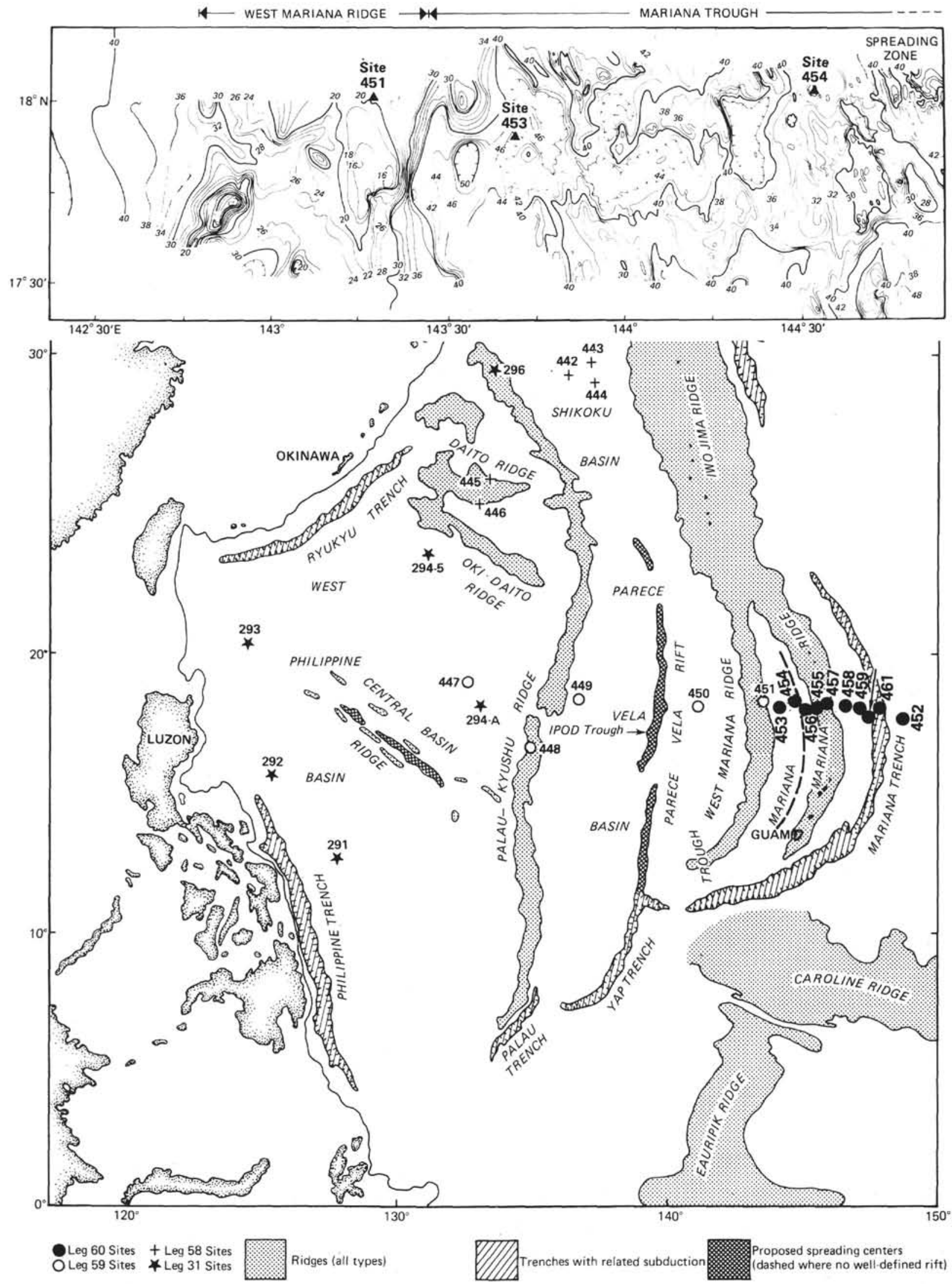

Figure 1. Location of DSDP sites drilled in the Philippine Sea. Site survey targets (SP numbers) are also indicated. Inset shows bathymetry of a portion of the Mariana Trough and West Mariana Ridge and locations of Sites 451, 453, and 454. Contours specified are in hundreds of meters (from Packham and Williams, this volume.) 


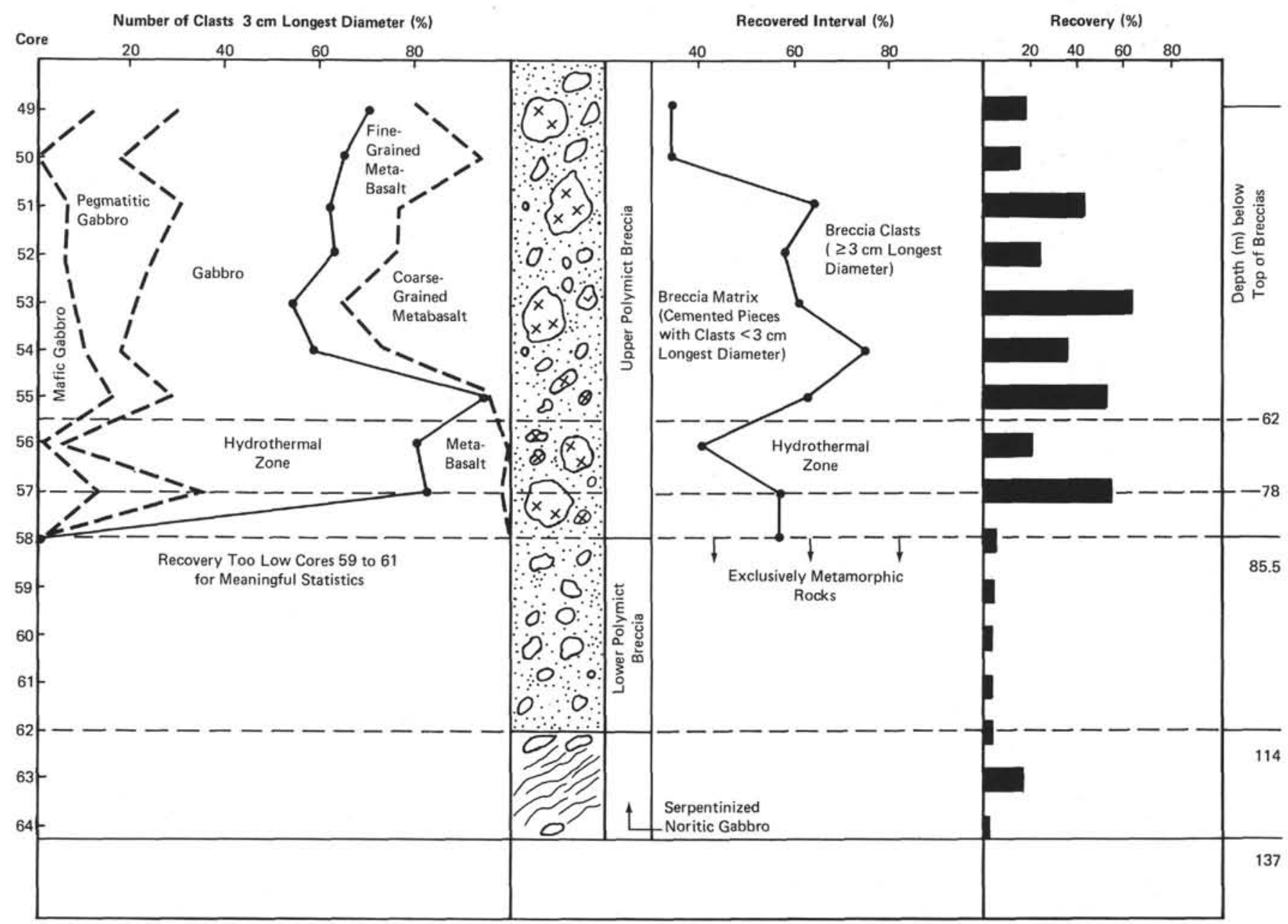

Figure 2. Stratigraphy, schematic lithology, and recovery per core of gabbro polymict breccias in Hole 453.

rock and thin section descriptions are on the igneous rock description forms at the end of that chapter. Additional information can be found in Sharaskin (this volume), Wood et al. (this volume) and Lawrence and Natland (this volume). For our purposes, it is sufficient to note that in the upper breccia, gabbro clasts form 50$90 \%$ of all clasts larger than $3 \mathrm{~cm}$ diameter in any given core, that the average gabbro clast is $7.6 \mathrm{~cm}$ long but there are gabbro boulders up to $46 \mathrm{~cm}$ in longest cored diameter, that metabasalt clasts are smaller on the average $(5.5 \mathrm{~cm})$ than gabbros and do not exceed $10 \mathrm{~cm}$ in longest cored diameter, and that there are two zones of particularly intense hydrothermal alteration in the hole. These are Cores 55 through 57 Section 2 in the upper breccia and Cores 58 through 63 in the lower breccia and sheared mafic gabbro. The 1.5 meters of sheared gabbro in Core 63 was evidently from a single large boulder and was nearly continuously cored.

\section{PETROGRAPHY}

The terminology for gabbros used herein is that of McCallum et al. (1980), except that for convenience I also allow mineralogic modifiers to be descriptive of the mode-as I shall explain momentarily. In the upper polymict breccia, there are three chemically and petrographically distinct types of gabbro and two types of metabasalt. Most gabbros are olivine-bearing, and there are four subtypes: troctolites (olivine anorthite gabbro with rare clinopyroxene), olivine gabbro, olivine anorthositic gabbro, and anorthositic olivine gabbro. The last three subtypes all have clinopyroxene, plagioclase, and olivine but are distinguished on the basis of the abundance of these minerals, respectively. From hand specimens it is evident that gradations among these types can occur within the same rock. This probably reflects cumulus layering in the original plutonic mass. Of the subtypes, olivine anorthositic gabbros are most abundant and troctolites least abundant.

The minor gabbro types are gabbro - which has abundant clinopyroxene and plagioclase and essential biotite but no olivine-and fine-grained amphibole gabbro which is plagioclase-rich but lacks both olivine and clinopyroxene. These two types are distinctly more sodic and less magnesian in composition than the olivinebearing gabbros and are also finer grained. They are minor lithologies scattered throughout the upper breccia and include the sheared mafic gabbro of Core 63 .

In addition to all these primary gabbro types, there are several distinctive metamorphosed and partially metamorphosed gabbros, plus rare recrystallized tonalites and quartz diorites (Sharaskin, this volume). In the upper breccia, the matrix consists of individual angular 
mineral grains broken from the coarser grained rocks set in an extremely fine-grained red or green cement. Virtually no breccia matrix was recovered in the lower breccia; what there was is soft, friable, and dark green.

\section{Olivine-bearing Gabbros (Plate 1)}

The olivine-bearing gabbro subtypes can best be described as a continuum of petrographic types with different modes but nearly identical mineral compositions. The major whole-rock geochemical differences depend primarily on the proportion of plagioclase or clinopyroxene and to a much lesser extent on olivine, which rarely makes up more than $20 \%$ of the mode except in the troctolites, which are rare and in which olivine may be $50 \%$ of the mode. The olivine is typically altered to clays, iron hydroxides, or serpentine and in some samples is completely altered. Orthopyroxene, if once present, is now completely altered and was not found despite diligent searching in any samples, by either optical or electron microprobe examination.

The olivines are granular to euhedral in outline and were evidently the first minerals to form in these rocks. The crystals are 3-5 mm in diameter. Many are surrounded by thin coronas of somewhat aluminous pale green magnesiohornblende that appears to have formed by a subsolidus reaction between olivine and plagioclase in the presence of water (see Mineralogy section).

Both clinopyroxene and plagioclase form large (0.5$10.0 \mathrm{~cm}$ ) mosaics of crystals. Plagioclases adjacent to each other have generally anhedral outlines, but plagioclase adjacent to clinopyroxene has regular, often euhedral crystal outlines. The clinopyroxene is almost invariably anhedral in outline and is commonly twinned. Many grains enclose smaller crystals of amphibole, similar in composition but somewhat less aluminous than the amphibole rims on the olivines just described. The inclusions are related to crystallographic features of the enclosing clinopyroxene crystals, such as cleavage.

In addition to the major silicate phases, these gabbros contain scattered, small euhedral magnetite crystals, usually forming less than $1 \%$ of the mode. The magnetite is generally partly replaced by a wormy, less reflective (cation-deficient?) oxide mineral, but in one sample it is quite abundant (over 10\%) and is associated with traces of green spinel.

The texture of these rocks does not seem entirely amenable to application of conventional terminology for cumulus rocks (Wager et al., 1960). Since olivine, the first mineral to form, is not sufficiently abundant to have trapped intercumulus material, the rocks cannot be considered orthocumulates. Locally, either plagioclase or clinopyroxene forms interlocking mosaics within which no other minerals occur; hence the rocks represent a type of adcumulus growth. For rocks in which two phases have adcumulus textures, the term heteradcumulate has been proposed (Brown, 1956). Rocks that combine the features of orthocumulates and adcumulates-that is, having abundant primocrysts surrounded by an adcumulus phase-are called mesocumulates. This term reasonably describes the troctolites. In the other olivine-bearing gabbros, however, the olivine primocrysts are not abun- dant and there are two adcumulus phases. Most of the gabbros thus seem to be intermediate between mesocumulates and heteradcumulates, with heteradcumulus texture predominating.

\section{Gabbros (Plate 2)}

Gabbros consist predominantly of pale green clinopyroxene and plagioclase, either of which can predominate, with minor biotite, ilmenite, and magnetite. Secondary clays, iron hydroxides, and chlorite can be quite abundant.

The clinopyroxene commonly shows a fine crisscrossed pattern of cleavage or parting (diallage). In one sample, the clinopyroxene has been completely altered and only this gridwork, highlighted by secondary iron hydroxides, remains.

All samples of this type examined petrographically show the effects of ductile deformation to a greater or lesser degree. The plagioclases in one sample are bent, and the clinopyroxenes in all of them show 100 twinning (e.g., Rayleigh, 1965). The sheared gabbro in Core 63 has a granoblastic texture where it has not been cataclastized, and its textural similarity to gabbros higher in the hole suggests that they had a similar source and that Core 63 does not represent a shear or fault zone in Hole 453 , as suggested in the site chapter.

The biotite occurs in clumps of crystals between feldspars and pyroxenes and is most abundant in gabbros with predominant plagioclase. It surrounds large, anhedral opaque minerals. These are mainly ilmenite with lesser magnetite that has traces of ilmenite exsolution lamellae. The biotite and opaques were the last minerals to crystallize and in one moderately deformed sample are not themselves recrystallized, bent, or granulated. This suggests that the gabbros were not entirely crystallized before deformation.

\section{Amphibole Gabbros (Plate 3)}

These samples, of which two were examined petrographically, show the most characteristic cumulus textures of all the gabbros. One of them consists of about equal proportions of plagioclase and amphibole, with lesser ilmenite and magnetite. The plagioclases are euhedral primocrysts, many showing oscillatory zoning, and are partially overgrown with postcumulus plagioclase. There is a considerable range in compositions of the plagioclase $\left(\mathrm{An}_{55-40}\right)$, reflecting the zoning and overgrowths. The feldspars are surrounded by anhedral green amphibole, which is commonly twinned. The magnetites are scattered along the amphibole grain boundaries, whereas ilmenite most commonly occurs as rounded grains enclosed by the amphiboles. Texturally, this rock is a mesocumulate.

The other amphibole gabbro is coarser grained, contains unzoned plagioclases interlocking with pale green amphibole, and has no opaque minerals. This rock is a heteradcumulate.

\section{Spinel-bearing Gabbro (Plate 4, Figs. 1 and 2)}

Of the recrystallized gabbros, one specimen in particular seems to have been subjected to particularly ex- 
treme conditions of temperature and $P\left(\mathrm{H}_{2} \mathrm{O}\right)$. This is a gabbro consisting of about equal parts of plagioclase and green amphibole, with abundant smaller crystals (which are nevertheless up to $1 \mathrm{~mm}$ diameter) of green spinel occurring in clusters in the rock. The sample, which was from the zone of intense hydrothermal alteration (Core 55), also experienced partial retrograde metamorphism. It is veined with chlorite and lesser epidote, which replace mainly amphibole and some of the spinel. The compositions of the plagioclases are similar to those in the olivine-bearing gabbros, and the amphiboles are similar in composition to the amphibole coronas around olivines in those rocks (see Mineralogy section). Other gabbros outside the hydrothermal zone have optically similar green spinel, although it is much rarer than in this rock. For these reasons, the spinels in this gabbro do not appear to have crystallized in response to the hydrothermal conditions but to have formed under subsolidus conditions similar to those that affected less transformed olivine-bearing gabbros.

\section{Metavolcanic Rocks (Plate 3)}

There are two types of metavolcanic rocks in the upper breccia: originally aphyric and plagioclase-phyric metabasalts. Before metamorphism, the plagioclase phenocrysts were strongly zoned individual crystals and glomerocrysts up to $1 \mathrm{~cm}$ in diameter. They are now mosaics of smaller crystals aligned along original twin planes. The groundmasses of these rocks have been completely recrystallized to fairly coarse granoblastic mosaics of green amphibole, plagioclase, brownish orange stilpnomelane, magnetite, chlorite, and minor sphene. The aphyric rocks are similar except they lack recrystallized phenocrysts.

Although the metabasalts are dull gray and sufficiently coarse grained to be mistaken for diabase in hand specimens, there is no mistaking their metamorphic textures in thin section. No relict pillow margins or any other features of the original flows have been preserved, apart from the phenocrysts, although evidently the rocks were quite fine grained before metamorphism.

In the lower breccia, extremely fine-grained greenstones, some speckled with calcite and pyrite, were recovered. Some of these were breccias, now completely indurated by metamorphism. The rocks have been reconstituted to albite-chlorite-epidote assemblages, the latter mineral forming veins in some of them. From their high $\mathrm{SiO}_{2}$ (Wood et al., this volume), we know they were originally andesites and dacites. Chemically, they have been more greatly modified than any of the metabasalts of the upper breccia, since they are now almost completely albitized and chloritized (see Chemistry section).

\section{Minor Lithologies}

Minor lithologies include hydrothermally altered gabbros in Cores 56 and 57, upper breccia metabasalts that experienced retrograde metamorphism to prehnite-pumpellyite facies (Sharaskin, this volume), and biotitebearing, partially deformed quartz diorite (Sharaskin, this volume). The hydrothermally altered gabbros have been completely demagnetized (Bleil, this volume), with plagioclases largely replaced by a pale micaceous mineral and mafic minerals replaced mostly by chlorite, serpentine, epidote, and actinolite. One gabbro in this zone has been almost entirely recrystallized to a plagioclaseprehnite-epidote(?) assemblage and could represent either metamorphism prior to breccia formation or the highest grade of hydrothermal alteration in the upper breccia (see Plate 4, Figs. 3-7).

\section{Upper Breccia Matrix (Plate 5)}

Mineral identifications in samples of the matrix surrounding gabbro and metabasalt clasts in the upper breccia were based on microscopic examination (in both transmitted and reflected light), X-ray diffraction, and scanning electron microscopy. Originally the matrix consisted solely of small angular rock and mineral fragments derived from crushing and granulation of the larger clasts and boulders. The matrix has been considerably recrystallized and cemented. The very topmost piece of cemented breccia in Core 49 is the only one with any remaining matrix void space, which is lined with drusy quartz (see fig. 1 of Lawrence and Natland, this volume). No other quartz occurs in the matrix. Below this, through two cores (corresponding to $19 \mathrm{~m}$ cored), the principal cementing mineral in the matrix is calcite, colored faint pink by iron hydoxides. To about Core 55, the breccia matrix is red and consists of chlorite, iron hydroxides, and loosely packed clays coating feldspars and other minerals. The iron hydroxides are derived from transformation of ferromagnesian silicates and magnetite and are particularly abundant where the original components of the matrix were broken, mainly from nearby metabasalts. Chips of plagioclase, and thin coronas of plagioclases at the edges of the gabbro and metabasalt clasts, have a creamy bleached appearance resulting from transformation to $\mathrm{K}$-feldspar (Lawrence and Natland, this volume).

Similar bleached chips and coronas are quite prominent in the hydrothermally altered zone of Cores 55 and 56 , where the breccia matrix is green and consists almost entirely of compactly layered chlorite. Below the hydrothermally altered zone, the matrix is again red, although there are patches of green chloritic cement.

\section{CHEMISTRY}

The average of 13 analyses of olivine-bearing gabbros and representative analyses of gabbro and amphibole gabbro are presented in Table 1 and are based on data in Wood et al. (this volume), Sharaskin (this volume) and Bougault et al. (this volume). Among the analyses used to compile the composition of average olivine-bearing gabbro are several with significant enrichments in $\mathrm{K}_{2} \mathrm{O}$, $\mathrm{Rb}$, and $\mathrm{Ba}$, redistributed from the breccia matrix by formation of chlorite during hydrothermal alteration. The covariances of $\mathrm{Rb}, \mathrm{Ba}$, and $\mathrm{Na}_{2} \mathrm{O}$ with $\mathrm{K}_{2} \mathrm{O}$ among olivine-bearing gabbros are shown on Figure 3, A-C. Since the trace elements show strong positive correlations with $\mathrm{K}_{2} \mathrm{O}$, their abundance in any given olivine gabbro also reflects mainly hydrothermal metasomat- 


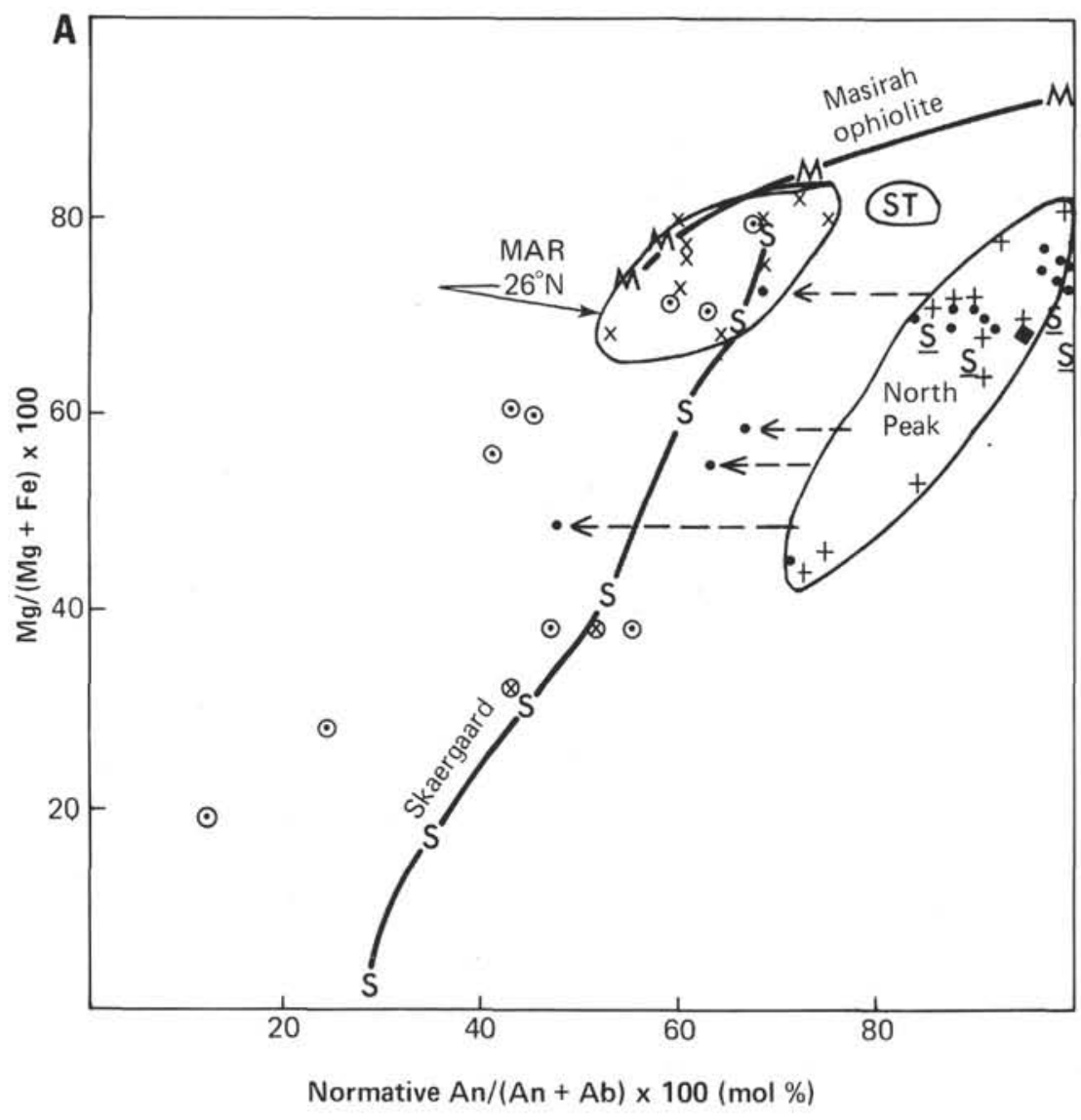

Calc-Alkalic Gabbros and Ejected Blocks

- Site 453

$<--$ possible albitization during hydrothermal and higher-grade greenschist facies metamorphism

- Average Agrigan cumulus mass (Stern, 1979)

+ North Peak, Peninsular Ranges, San Diego County, California (Nishimori, 1976).

S Soufriére Volcano, St. Vincent (Lewis, 1973)

Ocean-Floor Gabbros and Other Plutonic Rocks

$x$ Mid-Atlantic Ridge, $26 \mathrm{~N}$ (Tiezzi and Scott, 1980)

○ Gabbroic to granitic rocks, Indian Ocean Ridge (Engel and Fisher, 1975)

$\otimes$ Ferrogabbros, Mid-Atlantic Ridge (Mryashiro et al., 1970; Bonatti et al., 1971)

Layered Intrusions

S Skaergaard averages (Wager and Brown, 1967, table 6, p. 158)

(ST) Stillwater complex, field of analyses (Bowes et al., 1973)

\author{
Ophiolitic Gabbros \\ MMasirah ophiolite, Oman, \\ data in Wood et al. (this \\ volume)
}

Figure 4. A. $\mathrm{Mg} /(\mathrm{Mg}+\mathrm{Fe}) \times 100$ versus normative $\mathrm{An} /(\mathrm{An}+\mathrm{Ab}) \times 100$ for calc-alkalic gabbros compared with ocean crust, ophiolitic, and layered gabbro intrusions. B. $\mathrm{Mg} /(\mathrm{Mg}+\mathrm{Fe}) \times 100$ versus normative $\mathrm{An} /(\mathrm{An}+\mathrm{Ab}) \times 100$ for West Mariana Ridge and Agrigan Island, Mariana arc, lavas, compared with fields for Site 453 and the Peninsular Ranges, southern California batholith (Nishimori, 1976), and the average cumulus mass beneath Agrigan calculated by Stern (1979) to be responsible for the Agrigan fractionation trend (solid line). The effects of albitization on Hole 453 lower breccia metavolcanic samples is indicated by dashed arrows.

than gabbros and ultramafic rocks of the Masirah ophiolite in Oman (Wood et al., this volume), which is considered to have originated at an ocean ridge spreading center (Coleman, 1981; Hopson et al., 1981). This relationship is obvious despite probable $\mathrm{Na}$ enrichment of several of the gabbros as a consequence of hydrothermal alteration and applies also to the gabbros and amphibole gabbros.

Instead, the gabbros resemble those from a variety of calc-alkalic associations, as plotted on Figure 4A. These include ejected gabbroic blocks from Soufrière volcano, St. Vincent, Lesser Antilles Island arc (Lewis, 1973); zoned ultramafic gabbroic plutons in the Peninsular Ranges batholith of Southern California (Nishimori, 1976; Walawender, 1976; Walawender and Smith, 1980); and gabbroic xenoliths in calc-alkalic lavas of Agrigan volcano in the Mariana Island arc (Stern, 1979). The gabbros of Hole 453 also closely match the composition of a cumulus mass Stern (1979) inferred to underlie Agrigan, which he calculated by least-squares computer techniques to be responsible for the fractionation trend observed in Agrigan lavas (compare average compositions in Table 1, columns 1 and 2, and see Fig. 4B).

The metamorphosed basalts, andesites, and dacites of both the upper and lower breccias are considerably more sodic than their original igneous precursors (note on Figure $4 \mathrm{~B}$ that they plot far to the left-they have low $\mathrm{An} /(\mathrm{An}+\mathrm{Ab} \times 100)$-of little-altered calc-alkalic basalts and andesites of Site 451 on the West Mariana Ridge [Mattey et al., 1980] and the Mariana arc [Stern, 1979]). The most extreme $\mathrm{Na}$ enrichment is in the lower breccia where there is also extensive formation of chlorite. The combined effects of transformation of lower breccia lavas to a dominantly albite-chlorite mineral assemblage is shown on Figure 4B by the dashed arrows linking fresh and altered lavas compared at approximately the same $\mathrm{SiO}_{2}$ contents. The coarser-grained metabasalts of the upper breccia, which have experienced a higher grade of greenschist facies metamorphism - shifted only slightly to the left of the unmetamorphosed basalt composition on Figure 4B-retain more of their primary chemical compositions. Nevertheless, their original calc-alkalic lineage can more confidently be inferred from trace and minor element abundances (i.e., high $\mathrm{Sr}, \mathrm{Ba}$, and $\mathrm{K}$ ) and low $\mathrm{TiO}_{2}$ than from other major oxide abundances (Wood et al., this volume).

In summary, all of the rocks of Hole 453, including the gabbros, have calc-alkalic attributes. None of them are related in any way to intrusive or extrusive activity 


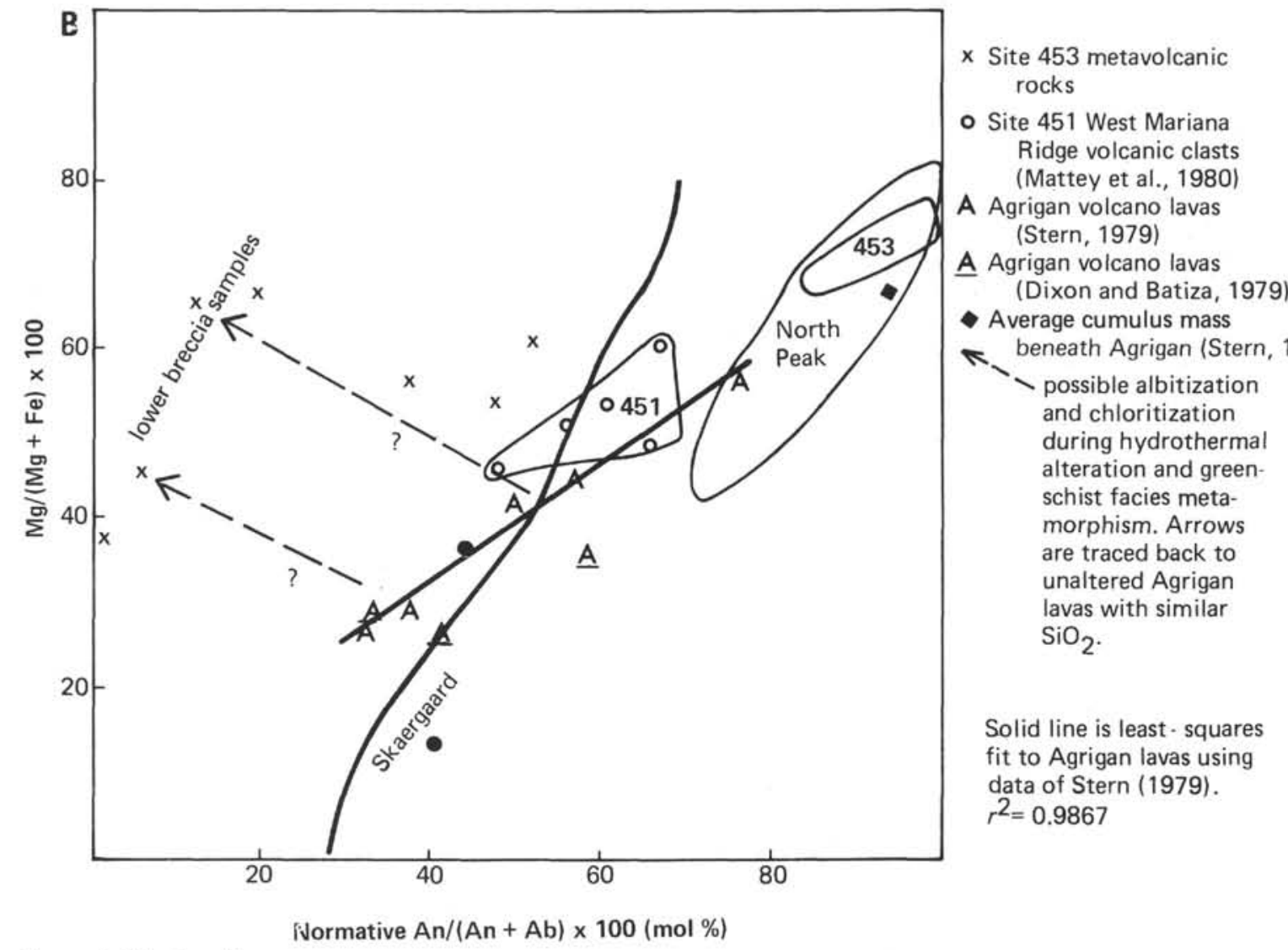

Figure 4. (Continued).

attending the opening of the Mariana Trough, in which basalts are much closer in composition to abyssal oceanic tholeiites (Fryer et al., this volume; Wood et al. this volume).

\section{MINERALOGY}

To elucidate the conditions of formation of the gabbros, electron microprobe analyses of mineral compositions were obtained at Scripps Institution of Oceanography using an auiomated Cameca electron microprobe. Instrumental corrections were made using standard programs. Reference standards for particular oxides were different, but well-analyzed olivine, pyroxene, and plagioclase standards were used for most oxides and were run as unknowns to determine final corrections-generally small-for some oxides. No corrections of this type were applied to spinels, micas, and opaque minerals.

The samples analyzed were two olivine-bearing gabbros, a recrystallized spinel gabbro, a gabbro, an amphibole gabbro, and a metabasalt-all from the upper breccia. They were selected from among the original collection of polished thin sections made on board Glomar Challenger. Petrographic descriptions of the specific samples, which are identified on the tables of mineral data, are included on the igneous rock description forms at the end of the Site 453 chapter. The mineralogies of the samples are described by rock type, in the same sequence as in the preceding section.

\section{Olivine-bearing Gabbros}

The high normative $\mathrm{An} /(\mathrm{An}+\mathrm{Ab}) \times 100$ of the olivine-bearing gabbros is borne out by the extremely calcic compositions of their plagioclases, which are anorthitic $\left(\mathrm{An}_{94-97}\right)$ (Table 2$)$. These highly calcic plagioclases are all the more unusual considering the surprisingly high iron contents of olivines $\left(\mathrm{Fo}_{76-77}\right)$ in the same samples (Table 3). Typical tholeiitic layered gabbroic intrusions rarely have such calcic plagioclase, yet what plagioclase they have is usually associated with more magnesian olivines. For example, the most calcic plagioclase in the Rhum layered complex $\left(\mathrm{An}_{90}\right)$ coexists with olivine of composition $\mathrm{Fo}_{90}$ (Brown, 1956). In the Bushveld complex, intercumulus plagioclase of composition $\mathrm{An}_{80}$ occurs in the basal peridotites in which olivine has compositions between $\mathrm{Fo}_{93}$ and $\mathrm{Fo}_{85}$ (Wager and Brown, 1967; Buchanan, 1975). Olivine is absent throughout much of the main mass of the intrusion but recurs near the top, where it is quite iron-rich $\left(\mathrm{Fo}_{21-51}\right)$ and coexists with plagioclases of compositions $\mathrm{An}_{45-53}$ (von Gruenewalt, 1973; Buchanan, 1975). At Cuillin, Isle of Skye, plagioclase of composition $\mathrm{An}_{84-88}$ coexists with olivine $\mathrm{Fo}_{84-87}$ (Weedon, 1965). Similarly, in the Samail ophiolite, gabbros have $\mathrm{An}_{80-85}$ coexisting with olivines of composition $\mathrm{Fo}_{72-80}$ (Pallister and Hopson, 1981). In short, the Hole 453 gabbros have mineralogical affinities with neither gabbros of stratiform complexes nor with an "oceanic" ophiolite complex. 
Coexisting plagioclases and olivines in the various calc-alkalic gabbro associations shown on Figure 4A, however, resemble those of the Hole 453 olivine-bearing gabbros. Lewis (1973) and Arculus and Wills (1980) report olivines with compositions of $\mathrm{Fo}_{60-80}$ in the same Lesser Antilles ejected gabbroic blocks as plagioclases of compositions $\mathrm{An}_{90-99}$. Nishimori (1976) reports olivines with compositions $\mathrm{Fo}_{70-79}$ coexisting with plagioclases of compositions $\mathrm{An}_{86-93}$ in peridotites and olivinebearing gabbros of the Peninsular Ranges batholith. Stern (1979) found that olivine of composition $\mathrm{Fo}_{74-82}$ coexists with plagioclase of compositions $\mathrm{An}_{88-96}$ in his xenoliths from Agrigan in the Mariana arc.

Pyroxenes in the olivine-bearing gabbros have the compositions of diopside and salite (Table 4). They have low $\mathrm{TiO}_{2}$ and tetrahedrally coordinated aluminum $\left(\mathrm{Al}^{\mathrm{IV}}\right)$, indicating that they did not crystallize from an alkalic magma (LeBas, 1962) and are similar to pyroxenes in the Soufrière plutonic ejecta (Lewis, 1973; Arculus and Wills, 1980), the Peninsular Ranges gabbros (Nishimori, 1976), and the Agrigan xenoliths (Stern, 1979). I was unable to identify orthopyroxene either optically or by means of the microprobe in the two olivine-bearing samples analyzed. Arculus and Wills (1980) found orthopyroxene to be concentrated in samples from the Lesser Antilles having plagioclases much less calcic than in olivine-bearing gabbros $\left(\mathrm{An}_{83-47}\right)$. Nishimori (1976) reports orthopyroxene as a reaction rim in olivine gabbros from the Peninsular Ranges batholith, but found it to be much more abundant in gabbros and noritic gabbros in the same zoned plutons. I found an extremely magnesian clay mineral adjacent to an olivine primocryst in one of the olivine-bearing gabbros from Hole 453 which may have been a similar orthopyroxene reaction rim, now entirely altered. Stern (1979) reported no orthopyroxene in his Agrigan xenoliths.

Amphiboles in the olivine-bearing gabbros of Hole 453 occur as blebs in clinopyroxenes and as narrow coronas surrounding olivines between grains of olivine and plagioclase. They have the compositions of rather aluminous magnesio-hornblendes and, in one case, tschermakitic hornblende (Table 5), based on the classification of the Subcommittee on the Amphibole Group of the International Mineralogical Association Commission on New Minerals and Mineral Names (Leake, 1978). The aluminous compositions compared to ideal hornblende are evident on Figure 5. In this respect, they compare to amphiboles in the Soufrière plutonic blocks and in the Peninsular Ranges gabbros, although on the whole they have lower $\mathrm{Na}+\mathrm{K}$ (Fig. 5). The K contents of the amphiboles are especially low (Table 5), suggesting a much lower $\mathrm{K}$ in the parent liquid of the Hole 453 gabbros than in either the Lesser Antilles or Peninsular Ranges gabbros (e.g., Helz, 1973). This accords with the generally low $\mathrm{K}_{2} \mathrm{O}$ in analyzed Mariana arc and West Mariana Ridge lavas (Dixon and Batiza, 1979; Stern, 1979; Mattey et al., 1980) compared to Lesser Antilles lavas (e.g., Brown et al., 1977) or to the tonalites and granodiorites of the Peninsular Ranges batholith (Larsen, 1948; Walawender and Smith, 1980).

Opaque minerals in the olivine-bearing gabbros of Hole 453 are magnetites with fairly high abundances of
$\mathrm{Al}_{2} \mathrm{O}_{3}, \mathrm{MgO}, \mathrm{TiO}_{2}$, and $\mathrm{Cr}_{2} \mathrm{O}_{3}$ (Table 6). In these respects they are similar to opaque minerals in the Lesser Antilles ejected blocks (Lewis, 1973) but differ from opaque minerals from the Peninsular Ranges gabbros reported by Nishimori (1976). In these rocks, the magnetites analyzed have lamellae of exsolved ilmenite, hence are low in $\mathrm{TiO}_{2}$. However, the abundances of $\mathrm{MgO}$, $\mathrm{Cr}_{2} \mathrm{O}_{3}$, and $\mathrm{Al}_{2} \mathrm{O}_{3}$ are comparable to those in magnetites of the Hole 453 and Lesser Antilles gabbros. Optical examination with reflected light of the opaques in the Hole 453 olivine-bearing gabbros revealed no exsolution lamellae, though most of them had undergone partial oxidative alteration.

\section{Spinel-bearing Gabbro}

Plagioclases in the recrystallized spinel gabbro have compositions nearly identical to those in the olivinebearing gabbros (Table 2). On this basis, the gabbro was almost certainly originally an olivine-bearing gabbro as well. However, all olivine and clinopyroxene has been converted to amphibole and green spinel.

The amphiboles analyzed in this sample have compositions almost identical to those forming coronas around olivines in the olivine-bearing gabbros (Table 5; Fig. 5) that is, they are somewhat aluminous magnesio-hornblendes, with not quite enough tetrahedrally coordinated $\mathrm{Al}$ to be termed tschermakitic. Rather than being a minor phase, however, in this sample amphibole forms nearly half the rock.

Spinels (Table 7) in this sample have compositions intermediate between spinel $\left(\mathrm{MgAl}_{2} \mathrm{O}_{4}\right)$ and hercynite $\left(\mathrm{Fe}^{2+} \mathrm{Al}_{2} \mathrm{O}_{4}\right)$, with very low $\mathrm{Cr}_{2} \mathrm{O}_{3}$. Spinels of this composition have not been reported from samples of the Lesser Antilles ejected blocks or from the xenoliths of Agrigan, but they do occur in the Peninsular Ranges gabbros (Nishimori, 1976, Walawender and Smith, 1980). However, in those samples they occur only as small grains associated with amphibole coronas in symplectites surrounding olivine. Nishimori (1976) attributes their formation to a subsolidus reaction between olivine and plagioclase in the presence of water, viz.:

$$
\mathrm{Ol}+\mathrm{Plag}+\mathrm{H}_{2} \mathrm{O} \rightarrow \text { Amph }+(\mathrm{Cpx} \text { and/or Opx })+\text { Spinel. }
$$

This reaction has been determined experimentally to occur at $7 \mathrm{kbar}$ pressure and at approximately $900^{\circ} \mathrm{C}$ (Yoder, 1966), although on the basis of field relations, Frost $(1974,1975)$ estimated pressures of $2-4$ kbar for a similar assemblage found in the metamorphosed peridotites at contact boundaries of the Mt. Stuart batholith in Washington.

\section{Gabbros}

Plagioclases in the gabbro sample examined by electron microprobe are more sodic and have a wider range of compositions $\left(\mathrm{An}_{53-69}\right)$ than in the olivine-bearing gabbros (Table 2). The particular sample has no unaltered clinopyroxene but has abundant intergrowths of biotite and opaque minerals. The biotite is quite ironrich (Table 8) and surrounds large irregular crystals of ilmenite (Table 6) and lesser magnetite. Arculus and Wills (1980) report that biotite in the Lesser Antilles 
Table 2. Electron microprobe analyses of plagioclases. ${ }^{\mathrm{a}}$

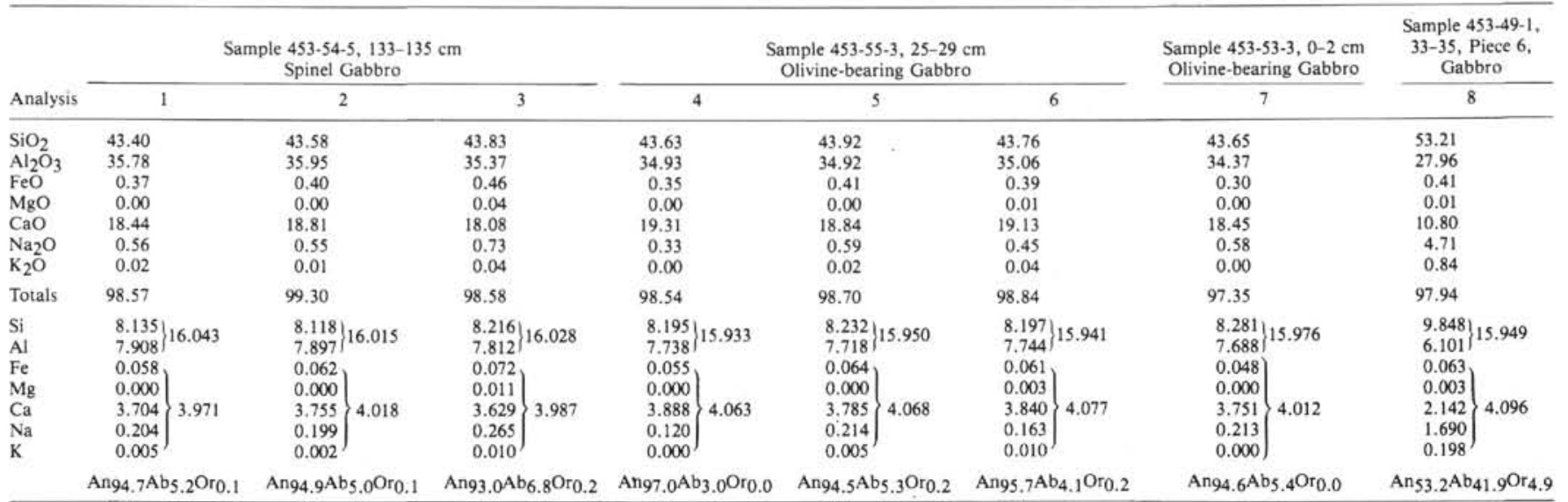

a Structural formulae on the basis of $32(0)$.

Table 3. Electron microprobe analyses of olivines in olivinebearing gabbros. ${ }^{\mathrm{a}}$

\begin{tabular}{|c|c|c|c|c|c|}
\hline \multirow[b]{2}{*}{ Analysis } & \multicolumn{2}{|c|}{$\begin{array}{c}\text { Sample } 453-53-3 \text {, } \\
0-2 \mathrm{~cm}\end{array}$} & \multicolumn{3}{|c|}{$\begin{array}{c}\text { Sample } 453-55-3, \\
25-29 \mathrm{~cm}\end{array}$} \\
\hline & 1 & 2 & 3 & 4 & 5 \\
\hline $\mathrm{SiO}_{2}$ & 38.42 & 38.35 & 38.01 & 38.00 & 38.11 \\
\hline $\mathrm{Al}_{2} \mathrm{O}_{3}$ & 0.00 & 0.00 & 0.03 & 0.02 & 0.02 \\
\hline $\mathrm{FeO}$ & 22.24 & 21.99 & 21.77 & 21.35 & 21.53 \\
\hline $\mathrm{MgO}$ & 39.45 & 39.18 & 40.28 & 40.36 & 40.44 \\
\hline $\mathrm{CaO}$ & 0.02 & 0.03 & 0.05 & 0.04 & 0.02 \\
\hline $\mathrm{NiO}$ & 0.04 & 0.04 & 0.05 & 0.01 & 0.01 \\
\hline $\mathrm{Cr}_{2} \mathrm{O}_{3}$ & 0.00 & 0.02 & 0.02 & 0.00 & 0.04 \\
\hline $\mathrm{MnO}$ & 0.38 & 0.39 & 0.49 & 0.44 & 0.40 \\
\hline Totals & 100.55 & 100.00 & 100.70 & 100.22 & 100.57 \\
\hline $\mathrm{Si}$ & 0.994 & 0.997 & 0.982 & 0.984 & 0.984 \\
\hline $\mathrm{Al}$ & 0.000 & 0.000 & 0.000 & 0.001 & 0.001 \\
\hline $\mathrm{Mn}$ & 0.008 & 0.009 & 0.011 & 0.010 & 0.009 \\
\hline $\mathrm{Ni}$ & 0.001 & 0.001 & 0.001 & $<0.001$ & $<0.001$ \\
\hline $\mathrm{Cr}$ & 0.000 & $<0.001$ & $<0.001$ & 0.000 & 0.001 \\
\hline $\mathrm{Fe}$ & 0.481 & 0.478 & 0.470 & 0.462 & 0.465 \\
\hline $\mathrm{Mg}$ & 1.521 & 1.518 & 1.551 & 1.558 & 1.556 \\
\hline & 0.001 & 0.001 & 0.001 & 0.001 & 0.001 \\
\hline \multirow[t]{2}{*}[\mathrm{Y}]{$^{6}$} & 2.012 & 2.006 & 2.034 & 2.032 & 2.032 \\
\hline & Fo 76.0 & Fo76.1 & Fo76.7 & Fo77.1 & Fo77.0 \\
\hline
\end{tabular}

a Structural formulae computed on the basis of $4(\mathrm{O})$.

samples occurs only in orthocumulates and agglomerative clusters and has a wide range in composition but is associated with relatively Fe-rich pyroxene and plagioclase of composition of approximately $\mathrm{An}_{40}$. They do not mention associated opaque minerals. Nishimori (1976) reports only minor abundances of biotite in Peninsular Ranges norites, where it is associated with plagioclase of composition $\mathrm{An}_{76-79}$, salitic clinopyroxene, hypersthene, amphibole, ilmenite, and magnetite. Larson and Draison (1950) present analyses of biotites from norites of the Peninsular Ranges similar to those reported here. It is possible that the Hole 453 gabbros originally contained hypersthene, which has since been altered, and hence were also noritic in composition.

The occurrence of late-formed aggregates of biotite, ilmenite, and magnetite, raises the question of whether they formed from trapped, hydrous, intergranular melts, or from a subsolidus reaction. If from an intergranular melt, it would have been exceptionally iron-rich and deficient in silica. There are no alkali feldspars or quartz near the biotites that suggest the presence of a silicic granophyre. Probably, therefore, the biotite formed by means of a subsolidus reaction after deformation of the gabbros.

\section{Amphibole Gabbro}

The minerals analyzed in the amphibole gabbro are plagioclase $\left(\mathrm{An}_{55-52}\right.$; Table 2; $\mathrm{An}_{55-35}$ estimated optically), hornblende (Table 5; Fig. 5), and ilmenite (Table 6). Although plagioclases as sodic as those in the amphibole gabbro were analyzed in the gabbro, most plagioclases in the gabbro are more calcic. Thus the amphibole gabbro is more evolved in terms of mineral compositions. This is also the case in the Peninsular Ranges gabbros (Nishimori, 1976; Walawender and Smith, 1980).

In contrast to the Peninsular Ranges gabbros and the Lesser Antilles ejected blocks, however, these are the only gabbros in the Hole 453 suite in which amphibole is a major mineral. Both Nishimori (1976) and Arculus and Wills (1980) describe olivine-bearing gabbros in which amphibole forms up to $40 \%$ of the mode. Their gabbros and norites also oftimes carry abundant amphibole. Probably, there is considerable sampling bias in the gabbro breccias, so that only a few out of the spectrum of possible gabbro types present beneath the West Mariana Ridge were incorporated into the breccias. The abundance of amphibole gabbros may be disproportionately low as a result.

\section{Metabasalt}

At this time, only a few minerals in a single metabasalt have been analyzed. They are included here primarily to provide contrast to the gabbro suite and to indicate something, if only a little, about contrasting conditions of pre- and postbreccia metamorphic processes.

The minerals analyzed in the metabasalt sample are plagioclase (Table 2) amphibole (Table 5), and chlorite (Table 8 ). The plagioclases include one clearly affected by $\mathrm{K}$-metasomatism. The unaltered plagioclase has a composition of about $\mathrm{An}_{50}$. Of the two amphiboles 
Table 2. (Continued).

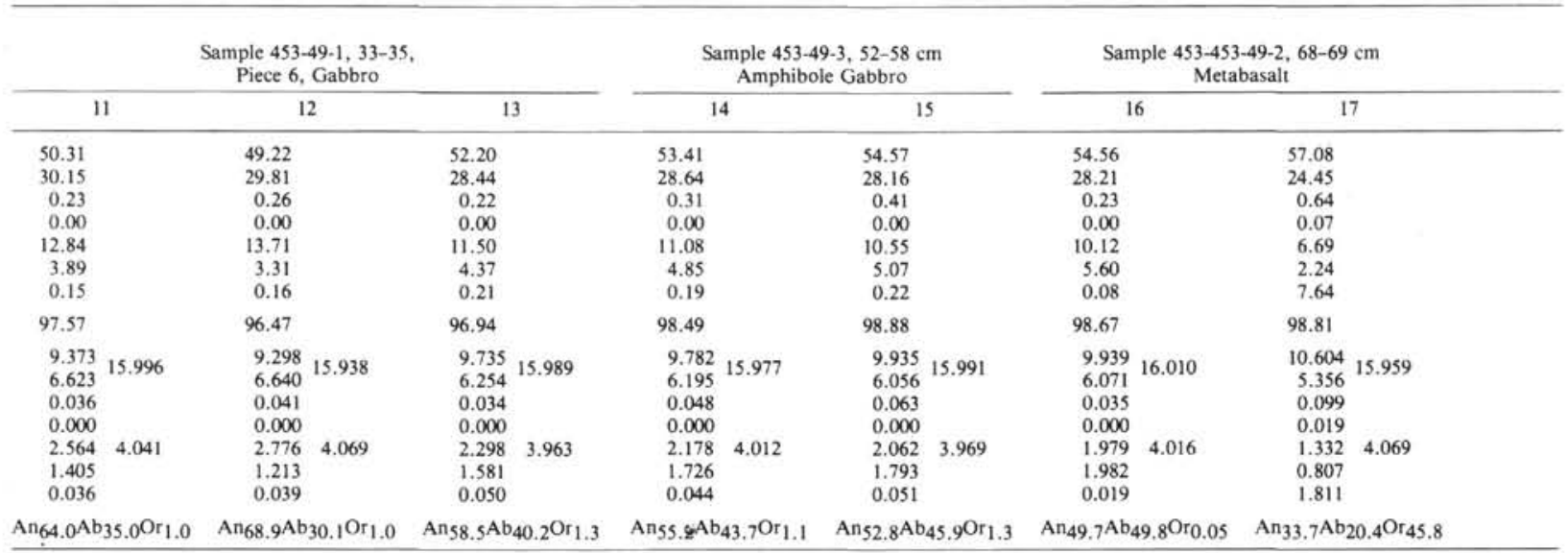

Table 4. Electron microprobe analyses of clinopyroxenes.

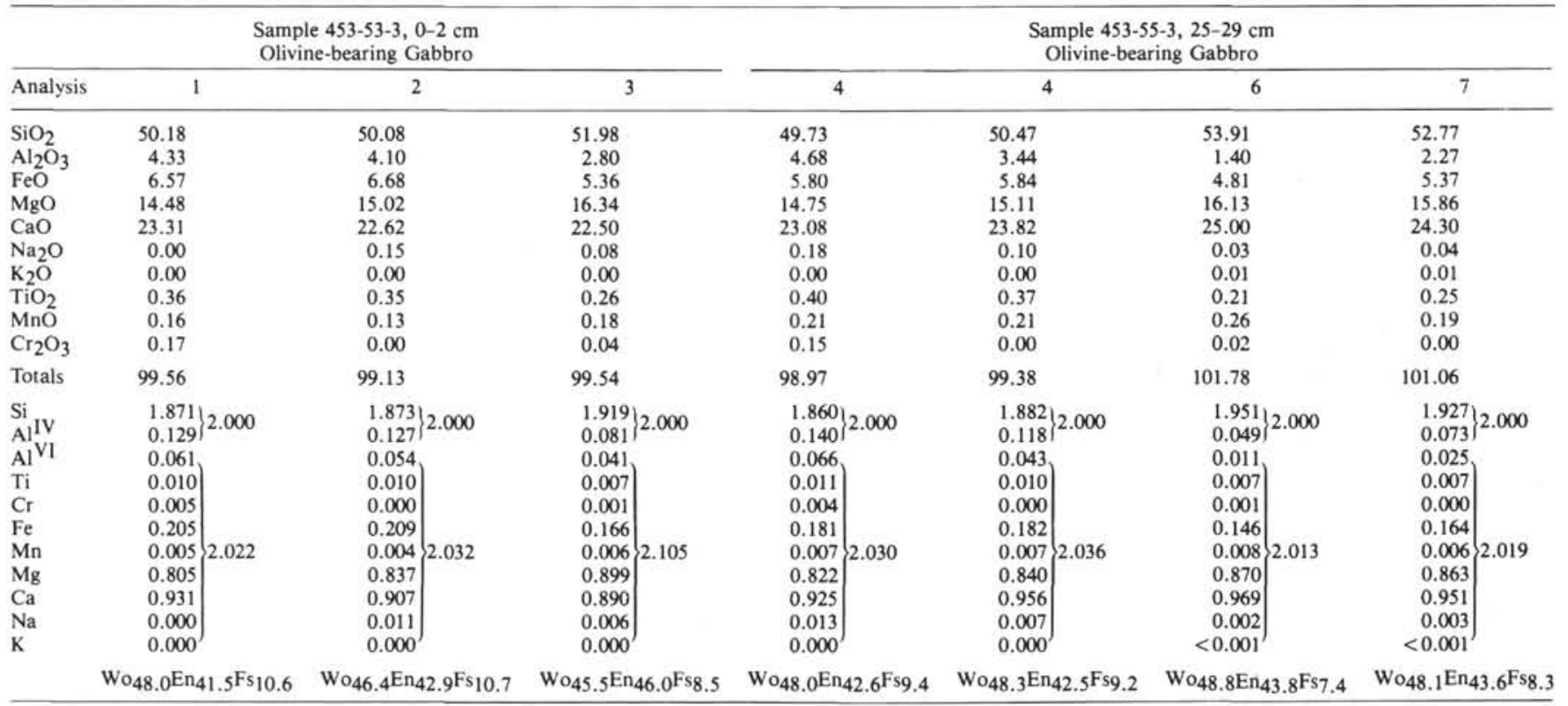

(Table 5), one is actinolitic and the other has the composition of magnesiohornblende. The chlorites contrast with two chlorites analyzed in the spinel gabbro (also in Table 8). Those in the metabasalt are somewhat less siliceous and aluminous but considerably more iron-rich and less magnesian than those in the spinel gabbro. That is, they are ripidolites rather than penninites. The chlorites in the spinel gabbro clearly reflect extraction of $\mathrm{Mg}$ from pore fluids during hydrothermal alteration, whereas in the metabasalts, $\mathrm{Fe}$ and $\mathrm{Mg}$ are derived solely from the host rock. One other metamorphic mineral was analyzed, an epidote group mineral occurring as an inclusion in a clinopyroxene crystal in one of the olivine gabbros (Table 8). It, too, probably formed during the episode of hydrothermal alteration, and has the composition of clinozoisite.

\section{Discussion}

On the basis of the chemical and mineralogical comparisons in the preceding sections, there can be little doubt that the Hole 453 gabbros belong to a class of gabbros that characteristically occurs in calc-alkalic island arcs. In the cases of the other gabbro suites, there has been general recognition that they could play an important role in calc-alkalic differentiation. Nishimori (1976), for example, pointed to the predominance in the Peninsular Ranges gabbro cumulates of anorthite, which has such low $\mathrm{SiO}_{2}$ that its fractionation forces residual melts to high $\mathrm{SiO}_{2}$ compositions. Nishimori (1976), Walawender and Smith (1980), and Arculus and Wills (1980) favor a parental liquid composition of basalt or basaltic andesite, not particularly rich in $\mathrm{MgO}$, based on the relatively iron-rich compositions of olivines. A similar conclusion could therefore be drawn from the Hole 453 olivine-bearing gabbros. Both Arculus and Wills (1980) and Stern (1979) present quantitative models for fractional crystallization; Stern (1979) comes closest to matching a calculated fractionation assemblage to an actual gabbro xenolith composition (Fig. 4B) that is very similar to Hole 453 olivine-bearing 
Table 5. Electron microprobe analyses of opaque minerals.

\begin{tabular}{|c|c|c|c|c|}
\hline & \multicolumn{2}{|c|}{$\begin{array}{c}\text { Magnetites } \\
453-53-3, \\
25-29 \mathrm{~cm} \\
\text { Olivine } \\
\text { Gabbro }\end{array}$} & $\begin{array}{l}\text { Ilme } \\
453-49-3, \\
52-58 \mathrm{~cm} \\
\text { Amphibole } \\
\text { Gabbro }\end{array}$ & $\begin{array}{c}453-49-1 \\
33-35 \mathrm{~cm} \\
\text { Gabbro }\end{array}$ \\
\hline & 1 & 2 & 3 & 4 \\
\hline $\mathrm{SiO}_{2}$ & 0.00 & 0.00 & 0.02 & 0.00 \\
\hline $\mathrm{Al}_{2} \mathrm{O}_{3}$ & 2.78 & 2.27 & 0.00 & 0.01 \\
\hline $\mathrm{FeO}^{*}$ & 84.91 & 84.18 & 47.26 & 44.78 \\
\hline $\mathrm{MgO}$ & 0.97 & 0.37 & 0.03 & 0.03 \\
\hline $\mathrm{CaO}$ & 0.03 & 0.07 & 0.14 & 0.03 \\
\hline $\mathrm{TiO}_{2}$ & 3.33 & 3.98 & 47.63 & 47.63 \\
\hline $\mathrm{Cr}_{2} \mathrm{O}_{3}$ & 1.19 & 1.51 & 0.01 & 0.04 \\
\hline $\mathrm{MnO}$ & 0.35 & 0.33 & 2.95 & 3.17 \\
\hline \multirow[t]{2}{*}{ Totals } & 93.56 & 91.20 & 98.04 & 95.69 \\
\hline & & & \multicolumn{2}{|c|}{$\begin{array}{l}\text { Structural Formulae on } \\
\text { the Basis of } 6(0)\end{array}$} \\
\hline $\mathrm{Si}$ & & & 0.001 & 0.000 \\
\hline $\mathrm{Ti}$ & & & 1.893 & 1.927 \\
\hline $\mathrm{Al}$ & & & 0.0002 .000 & 0.0012 .000 \\
\hline $\mathrm{Cr}$ & & & $<0.001$ & 0.002 \\
\hline $\mathrm{Fe}^{3+}$ & & & 0.105 & 0.070 \\
\hline $\mathrm{Mg}$ & & & 0.002 & 0.002 \\
\hline $\mathrm{Fe}^{2+}$ & & & $1.984 \quad 2.107$ & $1.945 \quad 2.072$ \\
\hline Mn & & & 0.113 & 0.123 \\
\hline $\mathrm{Ca}$ & & & 0.008 & 0.002 \\
\hline
\end{tabular}

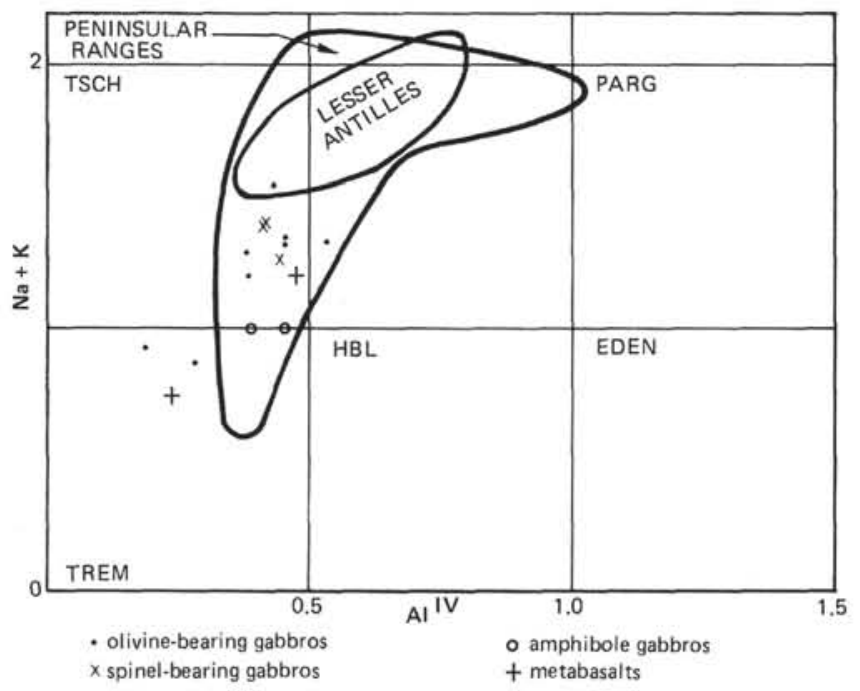

Figure 5. Tetrahedrally coordinated aluminum ( $\mathrm{Al}^{\mathrm{IV}}$ ) versus $\mathrm{Na}+\mathrm{K}$ for amphiboles of Table 5, compared with fields for the amphiboles of the Peninsular Ranges gabbros (Nishimori, 1976) and Lesser Antilles gabbroic blocks (Arculus and Wills, 1980). $\mathrm{HBL}=$ hornblende, TREM $=$ tremolite, $\mathrm{EDEN}=$ edenite, $\mathrm{PARG}=$ pargasite, $\mathrm{TSCH}=$ tschermakitic amphibole.

gabbros. The problem for the Lesser Antilles is more complex than for the Mariana arc because there is a greater range of both gabbro and lava compositions which need to be related. Arculus and Wills (1980) emphasize the role of amphibole and magnetite in enriching $\mathrm{SiO}_{2}$ in the course of calc-alkalic fractionation, even though amphibole does not occur as a phenocryst in most Lesser Antilles lavas. Lavas from the Mariana arc
(Stern, 1979; Dixon and Batiza, 1979) also lack amphibole phenocrysts, but their rather limited compositional range compared with the Lesser Antilles may be reflected in a more restricted range of gabbro types, with olivine-bearing gabbros being most abundant. Whatever the details of fractionation models, I concur with the sentiment of Arculus and Wills (1980) that "the very existence of cumulus assemblages is strong support for the hypothesis of fractional crystallization in the arc, and this process must be a significant factor in the development of the chemical characteristics of the various suites of rocks"' (pp. 790-791).

The conditions of crystallization can be deduced quantitatively from consideration of their mineralogies (e.g., Arculus and Wills, 1980). At this point, however, studies of mineral compositions in the Hole 453 gabbros are incomplete, and it would be premature to do this. Comparison to some of the other gabbro suites is instructive, however. On the basis of field evidence (grade of metamorphic aureoles, association with epizonal granodiorite and tonalite plutons, etc.), Nishimori (1976) inferred that the Peninsular Ranges gabbros crystallized at pressures of $5 \pm 2 \mathrm{kbar}$. Arculus and Wills (1980) inferred a wider range of pressures (4-10 kbar) for the Lesser Antilles blocks. Both studies concur in concluding that the highly calcic plagioclases result from elevated $P\left(\mathrm{H}_{2} \mathrm{O}\right)$. Arculus and Wills (1980) argue that something other than simple suppression of the plagioclase liquidus (Yoder, 1969) is involved. Instead, the shapes of the liquidus and solidus curves in the plagioclase- $\mathrm{H}_{2} \mathrm{O}$ system change (Johannes, 1978), causing melts to be in equilibrium with more calcic plagioclase. Both the Peninsular Ranges and Hole 453 gabbros are associated with metamorphic rocks that restrict inferences about depth of crystallization. In the Peninsular Ranges, gabbros have silimanite-bearing pyroxene hornfels contact aureoles (Nishimori, 1976). No such high grade metamorphic rocks occur among the Hole 453 breccias, but the abundant greenschist-facies metabasalts indicate that the gabbros were covered with at least several kilometers of volcanic ejecta. The sparse recrystallized tonalites in the breccias suggest that an association of gabbros and small silicic plutons with compositions similar to plutons in the Peninsular Ranges batholith exists beneath the West Mariana Ridge, although their scale can hardly have been comparable. A particularly intriguing indication of elevated water pressures in both the Peninsular Ranges and Hole 453 gabbros is the occurrence of compositionally similar green spinels and aluminous amphiboles in several of the rocks. If the experimental indications that the reaction that produced there minerals requires $7 \mathrm{kbar}$ water pressure (Yoder, 1966) are correct, these rocks must have experienced considerable uplift, up to $20 \mathrm{~km}$, to become exposed in the Mariana Trough. Even if the experiments overestimate the pressure for this reaction by a factor of two, uplift must still have occurred. It is important to note that such a pressure is consistent with the other estimates of depth of gabbro crystallization inferred by Nishimori (1976) for the Peninsular Ranges gabbros and would be consistent with the range of pressures inferred 
by Arculus and Wills (1980) for the Lesser Antilles blocks, if those minerals were to be discovered in them. Clearly, further study of the Hole 453 gabbro mineralogies is important, since it may bear considerably on the mechanism of initial rifting of the Mariana Trough.

There is no question that the gabbros are now exposed because of this rifting. Consolidated magma chambers deep within the West Mariana Ridge have been exposed by faulting. Probably the gabbros and metamorphic rocks were derived from surrounding ridges. The breccias do not have the typical high angle of repose of typical talus slopes, however. Instead, they are very nearly flat lying (see Site 453 chapter, this volume). Steep angles of repose are not necessarily the rule for material derived by mass wasting from steep submarine escarpments. Gabbroic material derived by simple mass wasting does occur in nearly flat-lying deposits in transform faults on the Mid-Atlantic Ridge (P. J. Fox, personal communication). Alternatively, nearly flat-lying breccias of the type cored in Hole 453 could be derived from catastrophic rock falls comparable to "stürtzstroms"' (Hsü, 1975), which are known to drop from cliffs and sweep across valley floors to form nearly flat-lying deposits. They are variously interpreted as having ridden a cushion of air, retaining internal coherence and attaining high velocities (Shreve, 1968), or to represent a type of particulate fluid flow that does not require an air or other fluid lubricant to reduce the effective stress between the moving mass and the ground (Hsü, 1975). Since there are two different breccias in Hole 453, containing different lithologies and clasts of different size ranges, there must be two discrete sources, favoring the interpretation that catastrophic rockfall occurred.

Following formation of the breccias, they were subjected to hydrothermal alteration to temperatures of at least $200^{\circ} \mathrm{C}$ (Lawrence and Natland, this volume). Formation of minerals such as chlorite, epidote, actinolite, and prehnite, however, occurs at temperatures considerably higher in a number of geothermal localities. Based on comparisons to Iceland (Tomasson and Kristmannsdottir, 1972) and the Salton Sea and Cerro Prietto geothermal wells (Elders et al., 1979; McDowell and Elders, 1980), temperatures of alteration in Hole 453 may actually have reached $350^{\circ} \mathrm{C}$ in some portions of the breccias. This is comparable to temperatures that attend mass flux of water and precipitation of sulfides at ocean spreading centers (e.g., RISE Project Group, 1980). Theoretical considerations (Lister, 1972, 1974) indicate that such high temperatures probably cannot be achieved without proximity of magma, hence it is probable that magmas were extruded or intruded near Hole 453 during the initial stages of rifting of the Mariana Trough. The rocks produced by such magmatism were not cored, however.

\section{ACKNOWLEDGMENTS}

Analytical costs for this study were defrayed by postcruise activities funds allocated to Leg 60. I thank Don Hussong and Yves Lancelot for approving the use of those funds. The assistance of Roy Fujita was instrumental. Stan Kling helped me obtain the scanning electron micrographs. I am also indebted to John Tarney and his colleagues for providing the bulk of the whole-rock chemical analyses used in this chapter, as reported in the chapter by Wood and others in this volume. I am grateful to John Tarney, Jim Hawkins, and Sherman Bloomer for many discussions relating to the problems of the gabbros and to Sherman Bloomer for going over the manuscript. I owe a special debt of gratitude to Dick Nishimori, whose dissertation on the Peninsular Ranges gabbros, undertaken while we were both students at Scripps Institution, provided so many parallels to the samples described here.

\section{REFERENCES}

Arculus, R. J., and Wills, K. J. A., 1980. The petrology of plutonic blocks and inclusions from the Lesser Antilles Island arc. $J$. Petrol., 21:743-799.

Bonatti, E., Honnorez, J., and Ferrara, G., 1971. Peridotite-gabbrobasalt complex from the equatorial Mid-Atlantic Ridge. Phil. Trans. Roy. Soc. London, A, 268:385-402.

Bowes, D. R., Skinner, W. R., and Skinner, D. L., 1973. Petrochemistry of the Stillwater Igneous Complex. Trans. Geol. Soc. S. Afr., 76:153-163.

Brown, G. M., 1956. The layered ultrabasic rocks of Rhum, Inner Hebrides. Phil. Trans. Roy. Soc. London, A, 240:1-53.

Brown, G. M., Holland, J. G., Sigurdsson, H., et al., 1977. Geochemistry of the Lesser Antilles volcanic island arc. Geochim. Cosmochim. Acta, 41:785-801.

Buchanan, D. L., 1975. The petrography of the Bushveld complex intersected by boreholes in the Bethal area. Trans. Geol. Soc. S. Afr., 78:335-348.

Coleman, R. G., 1981. Tectonic setting for ophiolite obduction in Oman. J. Geophys. Res., 86:2497-2508.

Dixon, T. H., and Batiza, R., 1979. Petrology and chemistry of Recent lavas in the northern Marianas: Implications for the origin of island arc basalts. Contrib. Mineral. Petrol., 70:167-181.

Elders, W. A., Hoagland, J. R., McDowell, S. D., et al., 1979. Hydrothermal mineral zones in the geothermal reservoir of Cerro Prieto. In Elders, W. A. (Ed.), Geology and Geothermics of the Salton Trough, GSA Guidebook, U.C. Riverside Campus Museum Contrib. 5:36-43.

Engle, C. G., and Fisher, R. L., 1975. Granitic to ultramafic rock complexes of the Indian Ocean Ridge system, western Indian Ocean. Geol. Soc. Am. Bull., 86:1553-1578.

Frost, R. B., 1974. Formation of plagioclase peridotite by contact metamorphism, Icicle Creek, central Cascades, Washington. Geol. Soc. Am. Abs. with Prog., 6:179-180. (Abstract)

1975. Contact metamorphism of serpentinite, chloritic blackwall, and rodingite at Paddy Go-easy Pass, Central Cascades, Washington. J. Petrol., 16:272-313.

Helz, R. T., 1973. Phase relations of basalts in their melting range at $\mathrm{P}_{\mathrm{H}_{2} \mathrm{O}}=5 \mathrm{~kb}$ as a function of oxygen fugacity. J. Petrol., 14: 249-302.

Hopson, C. A., Coleman, R. G., Gregory, R. T., et al., 1981. Geologic section through the Samail ophiolite and associated rocks along a Muscat-Ibra transect, southeastern Oman Mountains. J. Geophys. Res., 86:2527-2544.

Hsü, K. J., 1975. Catastrophic debris streams (stürtzstroms) generated by rockfalls. Geol. Soc. Am. Bull., 86:129-140.

Humphris, S. E., and Thompson, G., 1978. Hydrothermal alteration of oceanic basalts by seawater. Geochim. Cosmochim. Acta, 42: $127-136$.

Johannes, W., 1978. Melting of plagioclase in the systems Ab-An$\mathrm{H}_{2} \mathrm{O}$ and Qz-Ab-An- $\mathrm{H}_{2} \mathrm{O}$ at $\mathrm{PH}_{2} \mathrm{O}=5$ kbars, an equilibrium problem. Contrib. Mineral. Petrol., 66:295-303.

Kroenke, L., Scott, R. B., et al., 1980. Init. Repts. DSDP, 59: Washington (U.S. Govt. Printing Office).

Larsen, E. S., 1948. Batholith and associated rocks of the Corona, Elsinore, and San Luis Rey quadrangles. Geol. Soc. Am. Mem., 29:1-182.

Larsen, E. S., and Draisin, W. M., 1950. Composition of the minerals in the southern California batholith. Int. Geol. Congr., Rept. of 18th Sess., Great Britain, Part III: pp. 66-79.

Leake, B. J., 1978. Nomenclature of amphiboles. Can. Mineral., 16: 501-520.

LeBas, M. J., 1962. The role of aluminum in igneous clinopyroxenes with relation to their parentage. Am. J. Sci., 260:267-288.

Lewis, J. F., 1973. Petrology of the ejected plutonic blocks of the Soufrière volcano, St. Vincent, West Indies. J. Petrol., 14:81-112. 
Table 6. Electron microprobe analyses of amphiboles. ${ }^{\mathrm{a}}$

\begin{tabular}{|c|c|c|c|c|c|c|c|c|}
\hline \multirow[b]{2}{*}{ Analysis } & \multicolumn{3}{|c|}{$\begin{array}{c}\text { Sample 453-55-4, 133-135 cm } \\
\text { Spinel-bearing Gabbro }\end{array}$} & \multicolumn{3}{|c|}{$\begin{array}{c}\text { Sample } 453-53-3,0-2 \mathrm{~cm} \\
\text { Olivine-bearing Gabbro }\end{array}$} & \multicolumn{2}{|c|}{$\begin{array}{c}\text { Sample } 453-55-3,25-29 \mathrm{~cm} \\
\text { Olivine-bearing Gabbro }\end{array}$} \\
\hline & 1 & 2 & 3 & 4 & 5 & 6 & 7 & 8 \\
\hline $\mathrm{SiO}_{2}$ & 45.39 & 46.20 & 44.79 & 49.33 & 50.14 & 46.29 & 43.97 & 48.71 \\
\hline $\mathrm{Al}_{2} \mathrm{O}_{3}$ & 12.47 & 11.52 & 12.45 & 6.40 & 7.33 & 11.48 & 12.16 & 10.88 \\
\hline $\mathrm{FeO}$ & 9.98 & 9.21 & 9.26 & 7.11 & 6.70 & 8.21 & 9.89 & 7.11 \\
\hline $\mathrm{MgO}$ & 15.43 & 15.79 & 15.74 & 16.91 & 19.08 & 16.76 & 17.18 & 18.24 \\
\hline $\mathrm{CaO}$ & 11.38 & 11.22 & 11.20 & 16.41 & 12.15 & 12.43 & 10.84 & 12.64 \\
\hline $\mathrm{NaO}$ & 1.36 & 1.46 & 1.35 & 0.68 & 0.98 & 1.41 & 1.35 & 1.30 \\
\hline $\mathrm{K}_{2} \mathrm{O}$ & 0.13 & 0.17 & 0.14 & 0.01 & 0.08 & 0.34 & 0.25 & 0.17 \\
\hline $\mathrm{TiO}_{2}$ & 0.05 & 0.04 & 0.07 & 0.52 & 0.19 & 0.29 & 0.25 & 0.12 \\
\hline $\mathrm{MnO}$ & 0.27 & 0.17 & 0.16 & 0.14 & 0.07 & 0.13 & 0.14 & 0.15 \\
\hline Totals & 96.49 & 95.80 & 95.17 & 97.56 & 96.72 & 97.34 & 96.03 & 99.32 \\
\hline Si & 6.6028 .000 & $6.735\} 3.000$ & $6.585\} 8.000$ & $7.073 / 8.000$ & $7.134 / 8.000$ & $6.647\} 8.000$ & $6.446\} 8.000$ & 6.7898 .000 \\
\hline $\mathrm{Al}_{1}^{1 \mathrm{VI}}$ & $1.398)$ & $1.265)^{0.000}$ & $1.415)^{0.000}$ & $0.9277^{0.000}$ & $0.866 \int^{\circ .000}$ & $1.353 /^{\circ} .000$ & $1.554)^{0.000}$ & 1.201 \\
\hline & 0.741 & 0.715 & 0.743 & 0.115 & 0.364 & 0.591 & 0.548 & 0.587 \\
\hline $\begin{array}{l}\mathrm{Ti} \\
\mathrm{Mg}\end{array}$ & $\left.\begin{array}{l}0.006 \\
3.345\end{array}\right\} 5.000$ & $\left.\begin{array}{l}0.004 \\
3.431\end{array}\right\} 5.000$ & $\left.\begin{array}{l}0.008 \\
3.449\end{array}\right\} 5.000$ & $\begin{array}{l}0.056 \\
3.614\end{array}$ & $\begin{array}{l}0.020 \\
4.046\end{array} \leq .000$ & $\left.\begin{array}{l}0.031 \\
3.587\end{array}\right\} 5.000$ & $\begin{array}{l}0.0281 \\
3.754\end{array} \int^{5.000}$ & $\left.\begin{array}{l}0.013 \\
3.789\end{array}\right\}^{5.000}$ \\
\hline $\mathrm{Fe}$ & 0.908 ) & $0.850)$ & $0.800\}$ & $0.853\} 5.000$ & 0.570 & $0.791)$ & 0.670 & $0.611)$ \\
\hline $\mathrm{Fe}$ & 0.306 & $0.273)$ & 0.339 & 0.017 & 0.227 & 0.195 & 0.543 & 0.218 \\
\hline $\mathrm{Mn}$ & 0.0332 .113 & $0.021\} 2.047$ & $0.020\} 2.124$ & 0.305 & 0.0082 .088 & $0.015 \lcm{2.123}$ & $0.015\{2.261$ & $0.017\} 2.123$ \\
\hline $\mathrm{Ca}$ & 1.774 & $1.753)$ & $1.765)$ & $2.217)$ & $1.853)$ & $1.913)$ & $1.703)$ & $1.888)$ \\
\hline $\mathrm{Ng}$ & ${ }^{0.384} \mid 0.408$ & $0.413 \mid 0.445$ & $0.385\}_{0.411}$ & $0.819\} 0.191$ & $0.270\}_{0.285}$ & $0.393\} 0.455$ & $0.384\} 0.431$ & $0.351\} 0.381$ \\
\hline K & $0.024 /^{0.400}$ & $0.032 / 0.4$ & $0.026 /^{0.411}$ & $0.002 f^{f .131}$ & $0.015)^{0.205}$ & 0.062 & $0.047 f^{0.70}$ & $0.030 /$ \\
\hline Description ${ }^{b}$ & IC & IC & IC & RCPX & RCPX & RR & RR & RR \\
\hline $\begin{array}{c}\text { Type }^{\mathrm{c}} \\
\text { A }\end{array}$ & MH & MH & MH & $\mathrm{MH}$ & MH & MH & TH & MH \\
\hline
\end{tabular}

a Structural formulae on the basis of $23(\mathrm{O})$.

b $\mathrm{RCPX}=$ replaces clinopyroxene, $\mathrm{RR}=$ reaction rim on olivine, $\mathrm{IC}=$ individual crystal in groundmass, ICM=intercumulus mineral.

${ }^{\mathrm{c}} \mathrm{MH}=$ magnesio-hornblende, $\mathrm{TH}=$ tschermakitic hornblende, $\mathrm{H}=$ hornblende, $\mathrm{AH}=$ actinolitic hornblende.

Lister, C. R. B., 1972. On the thermal balance of a mid-ocean ridge. Geophys. J. Roy. Astr. Soc., 26:515-535.

1974. On the penetration of water into hot rock. Geophys. J. Roy. Astr. Soc., 39:465-509.

McCallum, I. S., Raedeke, L., and Mathez, E. A., 1980. Investigations of the Stillwater Complex: Part I. Stratigraphy and structure of the banded zone. Am. J. Sci., 280-A (Jackson Volume):59-87.

McDowell, S. D., and Elders, W. A., 1980. Authigenic layer silicate minerals in Borehole Elmore 1, Salton Sea Geothermal Field, California, USA. Contrib. Mineral. Petrol., 80:293-310.

Mattey, D. P., Marsh, N. G., and Tarney, J., 1980. The geochemistry, mineralogy and petrology of basalts from the West Philippine and Parece Vela Basins and from the Palau-Kyushu and West Mariana Ridges, Deep Sea Drilling Project Leg 59. In Kroenke, L., Scott, R. B., et al., Init. Repts. DSDP, 59: Washington (U.S. Govt. Printing Office), 753-800.

Miyashiro, A., Shido, F., and Ewing, M., 1970. Crystallization and differentiation in abyssal tholeiites and gabbros from mid-oceanic ridges. Earth Planet. Sci. Lett., 7:361-365.

Nishimori, R. K., 1976. The petrology and geochemistry of gabbros from the Peninsular Ranges Batholith, California, and a model for their origin [Ph.D. dissert.]. University of California, San Diego.

Pallister, J. S., and Hopson, C. A., 1981. Samail ophiolite plutonic suite: Field relations, phase variation, cryptic variation and layering, and a model of a spreading ridge magma chamber. J. Geophys. Res., 86:2593-2644.

Rayleigh, C. B., 1965. Glide mechanism in experimentally deformed minerals. Science, 150:739-741.

RISE Project Group, 1980. East Pacific Rise: Hot springs and geophysical experiments. Science, 207:1421-1433.
Shreve, R. L., 1968. Leakage and fluidization in air-layer lubricated avalanches. Geol. Soc. Am. Bull., 79:653-658.

Stern, R. J., 1979. On the origin of andesite in the northern Mariana Island arc: Implications from Agrigan. Contrib. Mineral. Petrol., 68:207-219.

Tiezzi, L. J., and Scott, R. B., 1980. Crystal fractionation in a cumulate gabbro, Mid-Atlantic Ridge, $26^{\circ}$ N. J. Geophys. Res., 85: 5438-5454.

Tomasson, J., and Kristmannsdottir, H., 1972. High temperature alteration minerals and thermal brines., Reykjanes, Iceland. Contrib. Mineral. Petrol., 36:123-134.

von Gruenewaldt, G., 1973. The main and upper zones of the Bushveld Complex in the Roossenekal area, eastern Transvaal. Trans. Geol. Soc. S. Afr., 76:207-227.

Wager, L. R., and Brown, G. M., 1967. Layered Igneous Rocks: San Francisco (Freeman).

Wager, L. R., Brown, G. M., and Wadsworth, W. J., 1960. Types of igneous cumulates. J. Petrol., 1:73-85.

Walawender, M. J., 1976. Petrology and emplacement of the Los Pinos pluton, southern California. Can. J. Earth Sci., 13:12881300 .

Walawender, M. J., and Smith, T. E., 1980. Geochemical evolution of the basic plutons of the Peninsular Ranges batholith, southern California. J. Geol., 88:233-242.

Weedon, D. S., 1965. The layered ultrabasic rocks of Sgurr Dubh, Isle of Skye. Scot. J. Geol., 1:42-68.

Yoder, H. S., 1966. Spilites and serpentinites. Ann. Rept. Dir. Geophys. Lab. Carnegie Inst. Washington Yearbook, 65:269-279.

1969. Calcalkalic andesites: experimental data bearing on the origin of their assumed characteristics. Oregon Dept. Mineral. Ind. Bull., 65:77-89. 
Table 6. (Continued).

\begin{tabular}{|c|c|c|c|c|c|c|}
\hline \multicolumn{3}{|c|}{$\begin{array}{c}\text { Sample } 453-55-3,25-29 \mathrm{~cm} \\
\text { Olivine-bearing Gabbro }\end{array}$} & \multicolumn{2}{|c|}{$\begin{array}{c}\text { Sample } 453-49-3,52-58 \mathrm{~cm} \\
\text { Amphibole Gabbro }\end{array}$} & \multicolumn{2}{|c|}{$\begin{array}{c}\text { Sample } 453-49-2,68-69 \mathrm{~cm} \\
\text { Metabasalt }\end{array}$} \\
\hline 9 & 10 & 11 & 12 & 13 & 14 & 15 \\
\hline 47.28 & 46.29 & 46.83 & 46.53 & 46.50 & 47.88 & 43.80 \\
\hline 10.81 & 11.48 & 11.08 & 6.62 & 6.39 & 5.39 & 8.38 \\
\hline 8.96 & 8.21 . & 8.18 & 17.49 & 17.79 & 20.20 & 21.99 \\
\hline 17.97 & 16.76 & 17.26 & 12.36 & 12.30 & 10.31 & 8.13 \\
\hline 11.62 & 11.89 & 12.40 & 10.70 & 10.44 & 11.56 & 10.86 \\
\hline 1.22 & 1.41 & 1.73 & 1.22 & 1.38 & 0.63 & 1.18 \\
\hline 0.26 & 0.34 & 0.31 & 0.22 & 0.25 & 0.62 & 0.61 \\
\hline 0.22 & 0.29 & 0.28 & 1.22 & 1.36 & 0.50 & 1.09 \\
\hline 0.16 & 0.13 & 0.14 & 0.60 & 0.69 & 0.46 & 0.59 \\
\hline 98.50 & 97.34 & 98.22 & 96.95 & 97.11 & 97.25 & 96.62 \\
\hline 6.703$\} 8.000$ & $6.671\} 8.000$ & $6.668\} 8.000$ & $6.997\{8.000$ & $6.998) 8.000$ & $7.250\} 8.000$ & $6.795\} 8.000$ \\
\hline $1.297^{0.000}$ & $1.329\}^{8.000}$ & $1.332^{8.000}$ & $1.003^{3.000}$ & $1.002\}^{0.000}$ & $0.750^{10.000}$ & $1.250^{\circ}$ \\
\hline 0.510 & 0.622 & 0.528 & 0.171 & 0.131 & 0.212 & 0.328 \\
\hline 0.023 & $0.031\}_{5000}$ & $0.031\}_{5}, 000$ & $0.138,5000$ & $0.154,5,000$ & $0.057\}_{5.000}$ & $0.127>5.000$ \\
\hline 3.798$\}^{5.000}$ & $3.6007^{5.000}$ & $3.663\}^{5.000}$ & $2.770\}^{5.000}$ & $2.7593^{5.000}$ & $2.327 \int^{5.000}$ & $1.8800^{.000}$ \\
\hline 0.669 ) & 0.747 ) & $0.778)$ & $1.921)$ & $1.956)$ & 2.404 & $2.665)$ \\
\hline 0.394 & 0.243 & 0.196 & 0.199 & 0.283 & 0.154 & 0.189 \\
\hline 0.019$\} 2.179$ & $0.015\} 2.094$ & $0.016\} 2.104$ & $0.076\} 1.999$ & 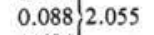 & $0.059\} 2.089$ & $0.078\{2.073$ \\
\hline 1.766 & $1.836)$ & 1.892 & 1.724 & $1.684)$ & $1.876)$ & $1.806)$ \\
\hline $\left.\begin{array}{l}0.355 \\
0.047\end{array}\right\} 0.382$ & $\left.\begin{array}{l}0.394 \\
0.063\end{array}\right\} 0.457$ & $\left.\begin{array}{l}0.478 \\
0.056\end{array}\right\} 0.534$ & $\left.\begin{array}{l}0.356 \\
0.042\end{array}\right\} 0.398$ & $\left.\begin{array}{l}0.403 \\
0.048\end{array}\right\} 0.451$ & $\left.\begin{array}{l}0.185 \\
0.057\end{array}\right\} 0.242$ & $\left.\begin{array}{l}0.355 \\
0.121\end{array}\right\} 0.476$ \\
\hline RR & RR & RR & ICM & $\mathrm{ICM}$ & IC & IC \\
\hline MH & MH & MH & $\mathrm{H}$ & $\mathrm{H}$ & $\mathrm{AH}$ & $\mathrm{MH}$ \\
\hline
\end{tabular}

Table 7. Electron microprobe analyses of spinels.

\begin{tabular}{|c|c|c|c|}
\hline \multirow[b]{2}{*}{ Analysis } & \multicolumn{3}{|c|}{$\begin{array}{c}\text { Sample } 453-55-4,133-135 \mathrm{~cm} \\
\text { Spinel-bearing Gabbro }\end{array}$} \\
\hline & 1 & 2 & 3 \\
\hline $\mathrm{SiO}_{2}$ & 0.17 & 0.11 & 0.00 \\
\hline $\mathrm{Al}_{2} \mathrm{O}_{3}$ & 62.51 & 63.74 & 63.94 \\
\hline $\mathrm{FeO}$ & 25.34 & 24.34 & 24.89 \\
\hline $\mathrm{MgO}$ & 12.44 & 11.05 & 13.13 \\
\hline $\mathrm{Cr}_{2} \mathrm{O}_{3}$ & 0.05 & 0.06 & 0.02 \\
\hline $\mathrm{NiO}$ & 0.04 & 0.00 & 0.02 \\
\hline $\mathrm{MnO}$ & 0.28 & 0.18 & 0.22 \\
\hline \multirow[t]{2}{*}{ Totals } & 100.83 & 99.52 & 102.22 \\
\hline & \multicolumn{3}{|c|}{$\begin{array}{l}\text { Structural Formulae on the } \\
\text { Basis of } 32(\mathrm{O})\end{array}$} \\
\hline $\mathrm{Si}$ & 0.04 & 0.02 & 0.00 \\
\hline $\mathrm{Al}$ & 15.62 & 16.03 & 15.70 \\
\hline $\mathrm{Fe}$ & 4.49 & 4.34 & 4.33 \\
\hline $\mathrm{Mg}$ & 3.93 & 3.51 & 4.07 \\
\hline $\mathrm{Cr}$ & 0.01 & 0.01 & $<0.01$ \\
\hline $\mathrm{Ni}$ & 0.01 & 0.00 & $<0.01$ \\
\hline \multirow[t]{2}{*}{$\mathrm{Mn}$} & 0.05 & 0.03 & 0.04 \\
\hline & 24.15 & 23.94 & 24.15 \\
\hline
\end{tabular}




\section{J. H. NATLAND}

Table 8. Electron microprobe analyses of biotites, chlorites, and an epidote-group mineral.

\begin{tabular}{|c|c|c|c|c|c|c|c|c|}
\hline $\mathrm{Al}_{2} \mathrm{O}_{3}$ & 14.00 & 13.96 & 16.78 & & 15.19 & 18.39 & 19.39 & 30.06 \\
\hline $\mathrm{FeO}$ & 24.94 & 22.98 & 27.77 & & 26.44 & 8.24 & 9.43 & 5.47 \\
\hline $\mathrm{MgO}$ & 8.13 & 8.85 & 12.47 & & 10.26 & 24.32 & 25.92 & 1.77 \\
\hline $\mathrm{K}_{2} \mathrm{O}$ & 8.18 & 8.60 & 0.72 & & 3.02 & 0.01 & 0.00 & 0.03 \\
\hline $\mathrm{TiO}_{2}$ & 3.17 & 3.83 & 0.35 & & 1.46 & 0.01 & 0.00 & 0.02 \\
\hline MnŌ & 0.15 & 0.13 & 0.32 & & 0.19 & 0.84 & 0.87 & 0.23 \\
\hline \multirow[t]{2}{*}{ Totals } & 93.16 & 93.64 & 85.12 & & 85.51 & 85.29 & 85,98 & 97.07 \\
\hline & \multicolumn{2}{|c|}{$\begin{array}{l}\text { Structural Formulae } \\
\text { Calculated on the } \\
\text { Basis of } 22(\mathrm{O})\end{array}$} & \multicolumn{3}{|c|}{$\begin{array}{l}\text { Structural Formulae } \\
\text { Calculated on the } \\
\text { Basis of } 28(\mathrm{O})\end{array}$} & \multicolumn{2}{|c|}{$\begin{array}{l}\text { Structural Formulae } \\
\text { Calculated on the } \\
\text { on the Basis of } 28(\mathrm{O})\end{array}$} & $\begin{array}{c}\text { Structural Formulae } \\
\text { on the Basis } \\
\text { of } 13(\mathrm{O})\end{array}$ \\
\hline $\mathrm{Ti}$ & 0.383 & 0.453 & 0.059 & & 0.244 & 0.001 & 0.000 & 0.001 \\
\hline $\mathrm{Fe}$ & $3.353\} 5.890$ & $3.020\} 5.757$ & 5.170 & & 3.392 & 1.364 & 1.554 & 0.374 \\
\hline $\mathrm{Mn}$ & 0.020 & 0.017 & 0.060 & & 0.036 & 0.141 & 0.145 & 0.016 \\
\hline $\mathrm{Mg}$ & 1.948 & $2.073)$ & 4.137 & 12.046 & $3.392\}^{11.881}$ & $7.172\}^{11.616}$ & $7.614\}^{11.798}$ & 0.216 \\
\hline $\mathrm{Ca}$ & 0.005 & 0.003 & 0.017 & & 0.012 & 0.371 & 0.030 & 1.841 \\
\hline $\mathrm{Na}$ & $0.044\} 1.727$ & $0.046\} 1.773$ & 0.134 & & 0.099 & 0.023 & 0.000 & 0.003 \\
\hline K & 1.678 & 1.724 & 0.204 & & 0.855 & 0.003 & $0.000)$ & 0.001 \\
\hline
\end{tabular}



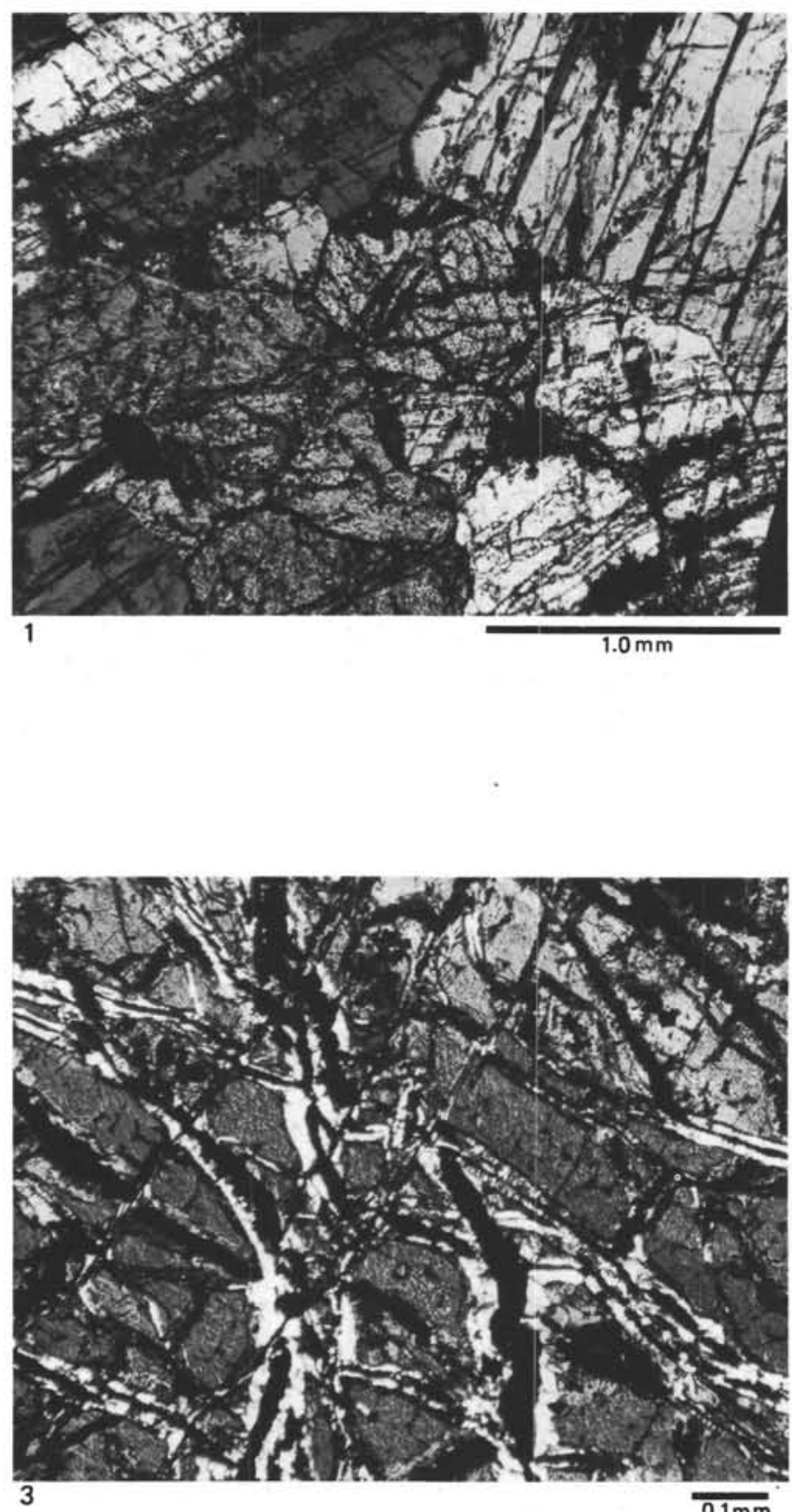

Plate 1. Petrographic features of olivine-bearing gabbros.

Figure 1. Sample 453-55-3, 25-29 cm. Interlocking plagioclase crystals in heteradcumulus gabbro, crossed nichols.

Figure 2. Sample 453-54-4, 133-135 cm. Relict interlocking plagioclase crystals in formerly olivine-bearing (now spinel-bearing) gabbro, crossed nichols.
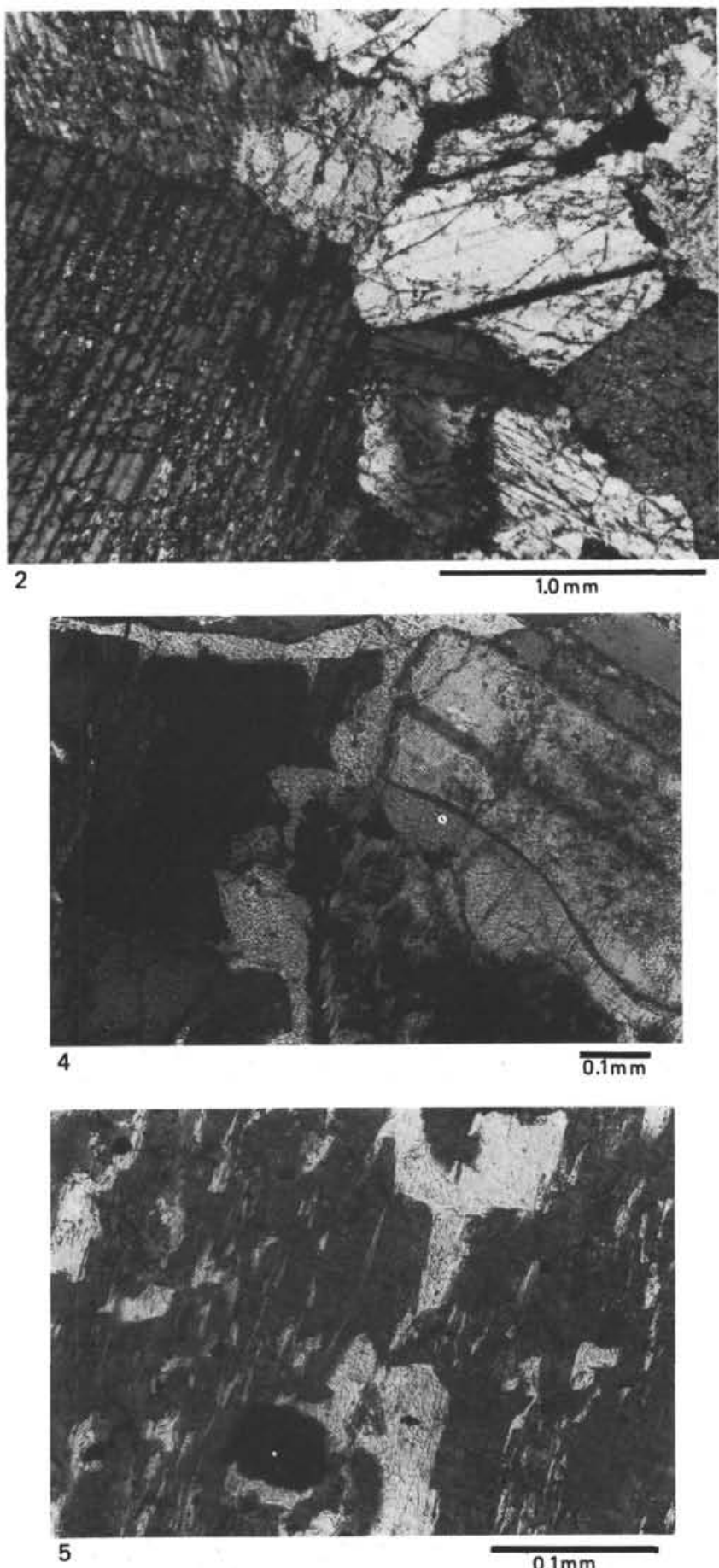

Figure 3. Sample 453-55-3, 25-29 cm. Partially serpentinized olivine with magnetites in serpentine veinlets, crossed nichols.

Figure 4. Sample 453-53-3, 0-2 cm. Amphibole (low relief) between altered olivine (dark, at left) and fresh plagioclase (clear, high relief, at right), plane light.

Figure 5. Sample 453-53-3, 0-2 cm. Amphibole blebs within clinopyroxene, crossed nichols. 

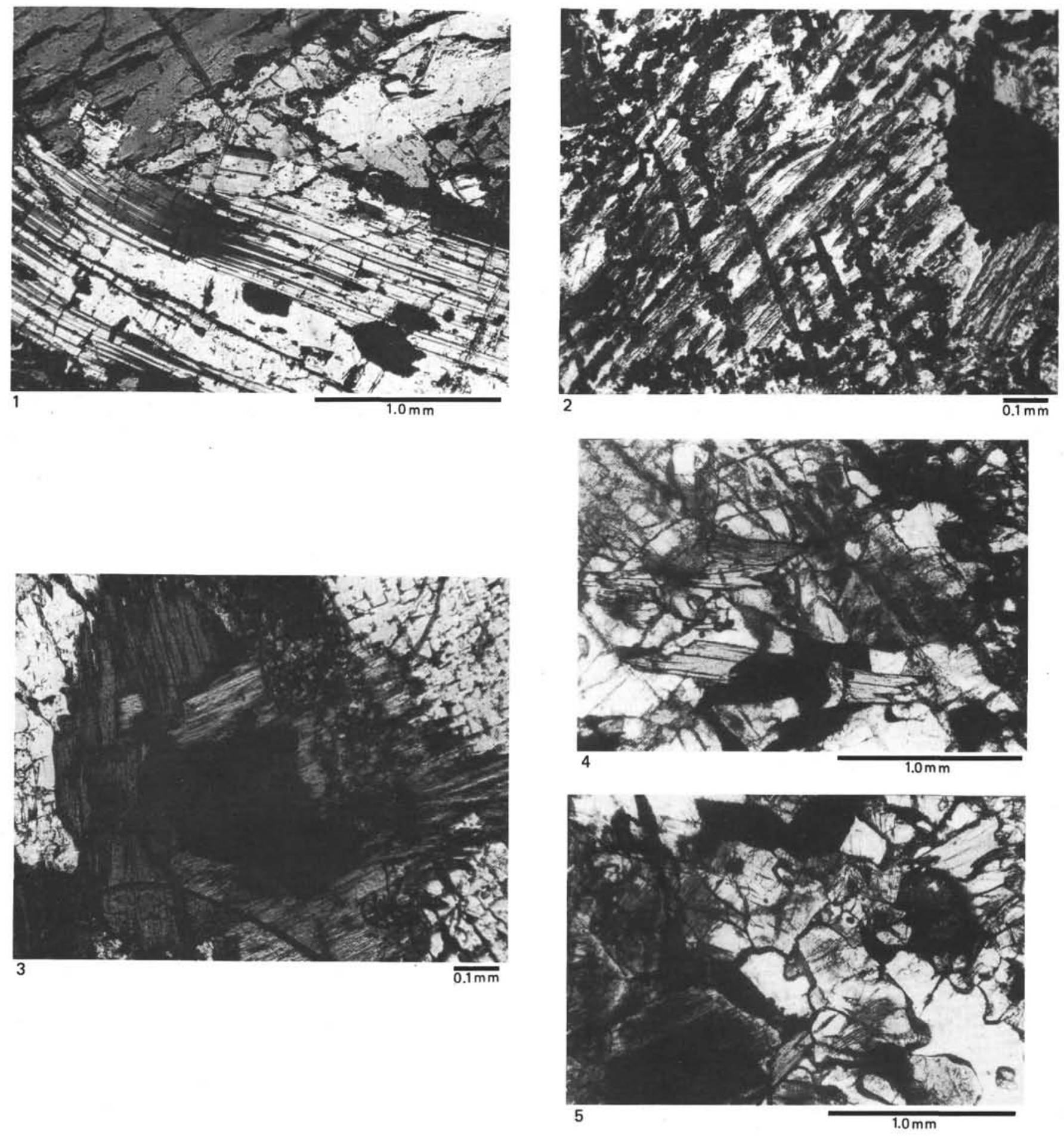

Plate 2. Petrographic features of gabbros.

Figure 1. Sample 453-49-1, 33-35 cm. Bent plagioclase crystals, crossed nichols.

Figure 2. Same sample as Fig. 1. Secondary gridwork of iron hydroxides following original cleavage and parting of a clinopyroxene crystal. Plane light.

Figure 3. Same sample as Fig. 1. Biotite-ilmenite intergrowth. Plane light.

Figure 4. Sample 453-63-1, 80-83 cm. Biotite and opaque minerals in predominantly clinopyroxene groundmass.

Figure 5. Same sample as Fig. 4, showing diallage on clinopyroxenes. 

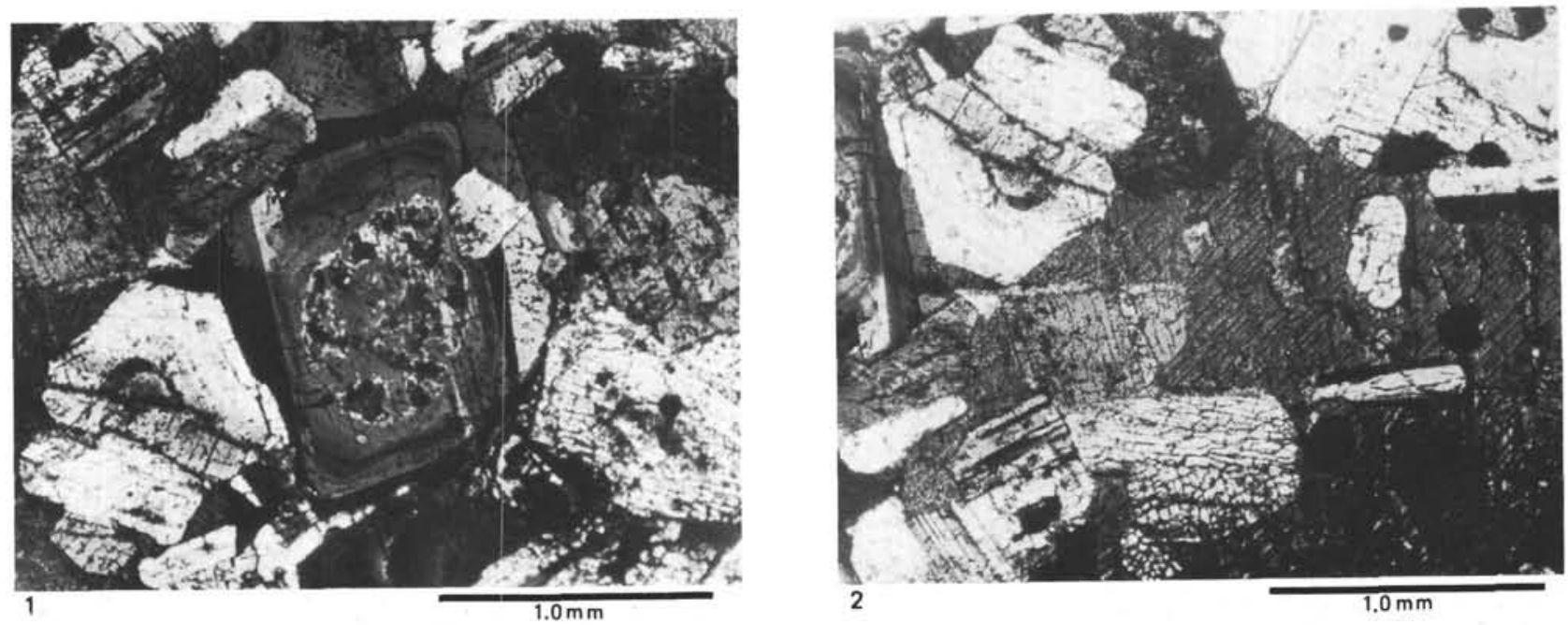

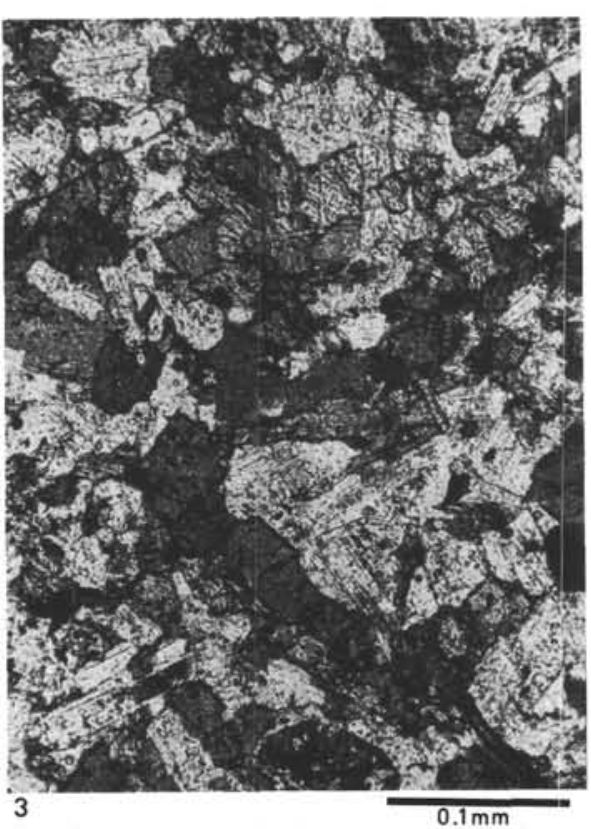

Plate 3. Amphibole gabbro and metabasalts.

Figure 1. Sample $453-49-3,52-58 \mathrm{~cm}$. A zoned, partly altered plagioclase primocryst in amphibole gabbro, crossed nichols.

Figure 2. Same sample as Fig. 1. Plagioclase primocrysts and intercumulus amphibole, plus minor opaque minerals, crossed nichols.
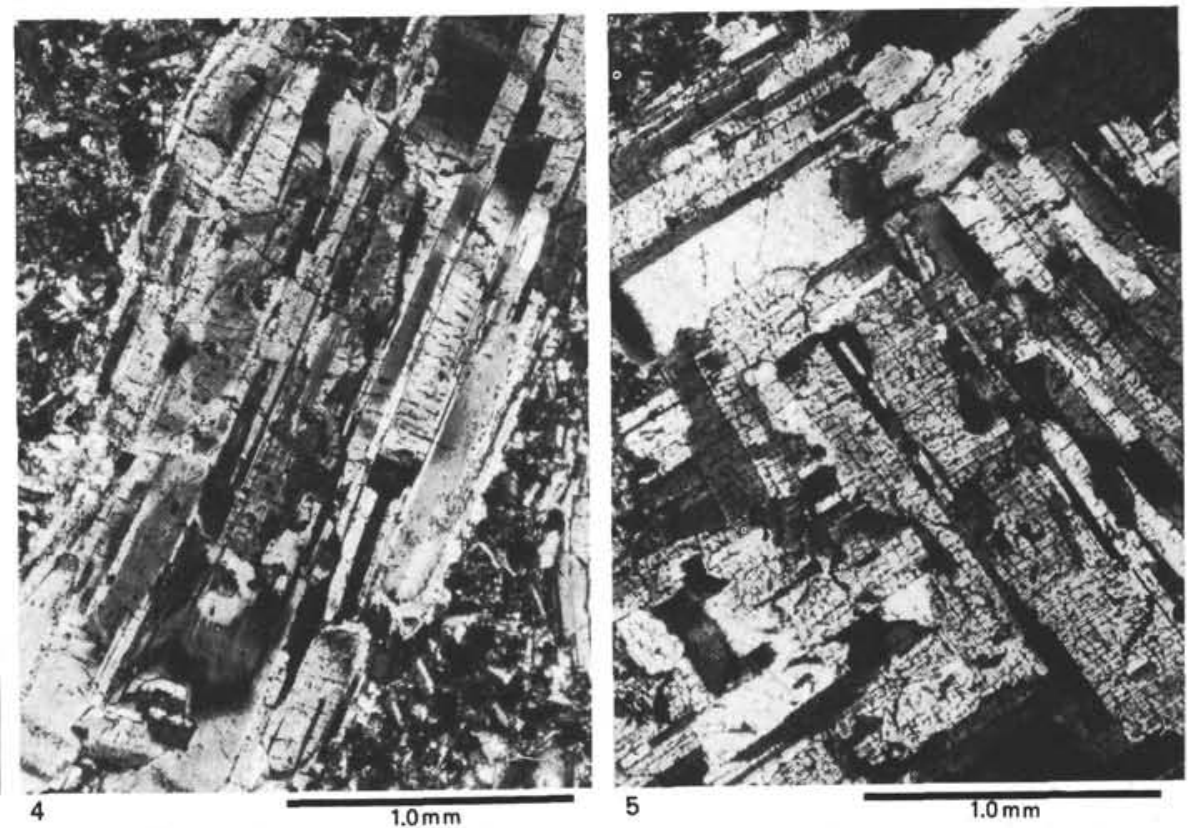

Figure 3. Sample 453-54-3, 55-58 cm. Metabasalt. Granoblastic plagioclase, chlorite, and amphibole. Plane light.

Figure 4. Sample 453-52-1, 99-102 cm. Metabasalt. Plagioclase porphyroblast, a recrystallized phenocryst in chlorite-plagioclase-stipnomelane-epidote groundmass, crossed nichols.

Figure 5. Same sample as Fig. 4. Center of large recrystallized plagioclase glomerocryst. 

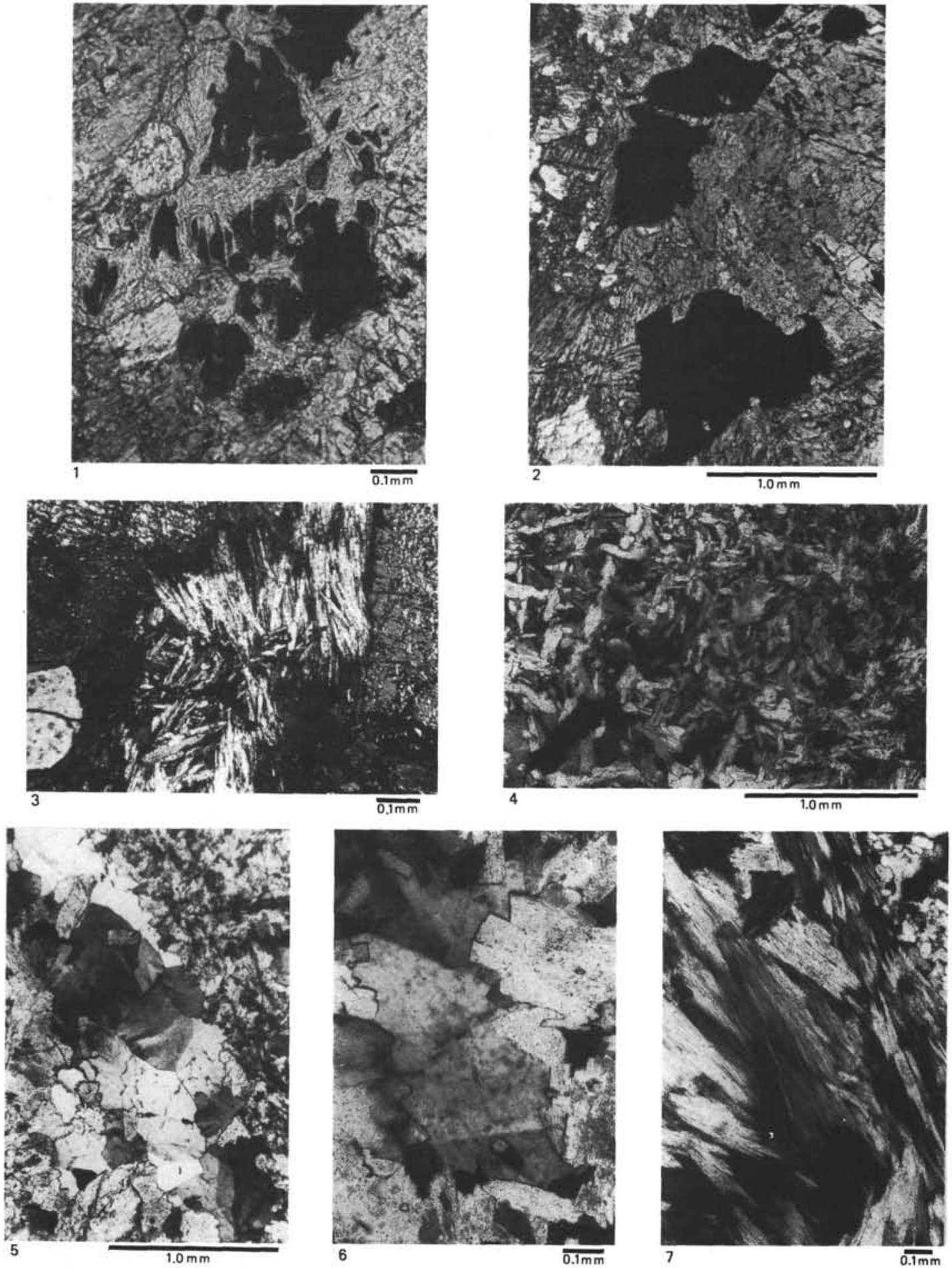

Figure 3-7. Sample 453-56-2, 85-87 cm. All crossed nichols. The sample consists of two principal zones, partially recrystallized and en tirely recrystallized. The partially recrystallized zones retain primary plagioclase but have mafic minerals replaced by actinolite (veinlet in Fig. 3) and chlorite (dark areas near veinlet Fig. 3). The entirely recrystallized zones are either fine-grained and granoblastic intergrowths of epidote and plagioclase (Fig. 4) or coarsergrained patches of a zeolite (laumontite?) $\pm \mathrm{K}$-feldspar + epidote (Figs. 5 and 6) with sprays of prehnite (Fig. 7). Veinlets of this mineral assemblage cross relict plagioclases and chlorite-actinolite patches and therefore represent a retrograde episode of metamorphism. 


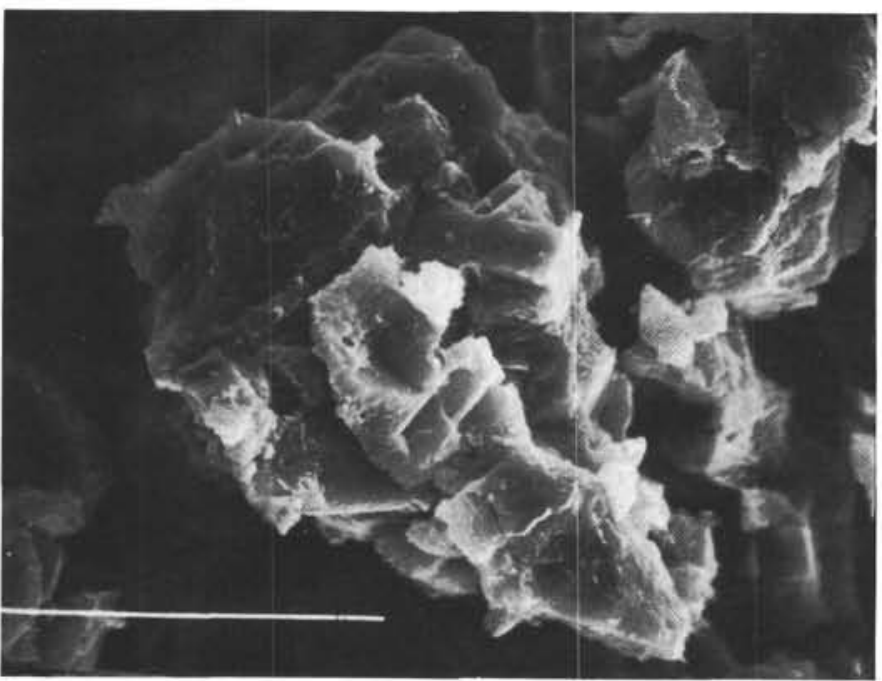

1

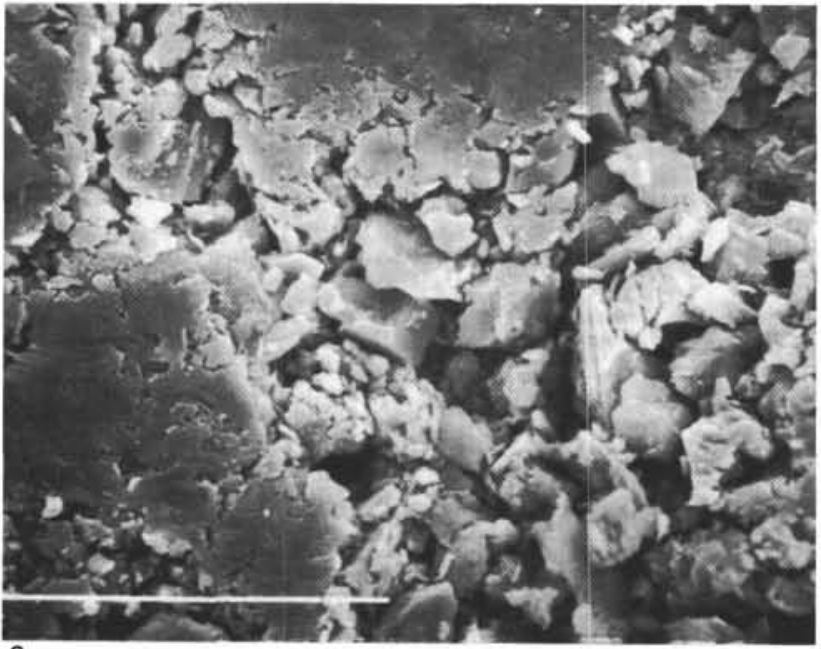

3

Plate 5. Scanning electron micrographs of cementing minerals in the upper breccia matrix. The first three micrographs are of the oxidized red matrix; the fourth, of the green matrix in the hydrothermally altered zone of Cores 55-57.

Figure 1. Sample 453-51-1, 69-72 cm, Piece \#10. Clay-cemented feldspars. Energy-dispersive X-ray (EDAX) qualitative analysis of the crystal at upper right, central clump, gave principal peaks for $\mathrm{K}$, $\mathrm{Al}$, and $\mathrm{Si}$, indicating that the grain is almost pure $\mathrm{K}$-feldspar. The small scale bar on the micrograph $=0.1 \mathrm{~mm}$.

Figure 2. Same sample as Fig. 1. Close-up of clays coating surface of clump at upper right. EDAX qualitative analysis gave principal peaks for $\mathrm{K}, \mathrm{Fe}, \mathrm{Si}$, and $\mathrm{Al}$, with lesser $\mathrm{Mg}$, indicating $\mathrm{K}-\mathrm{Fe}$ smec-

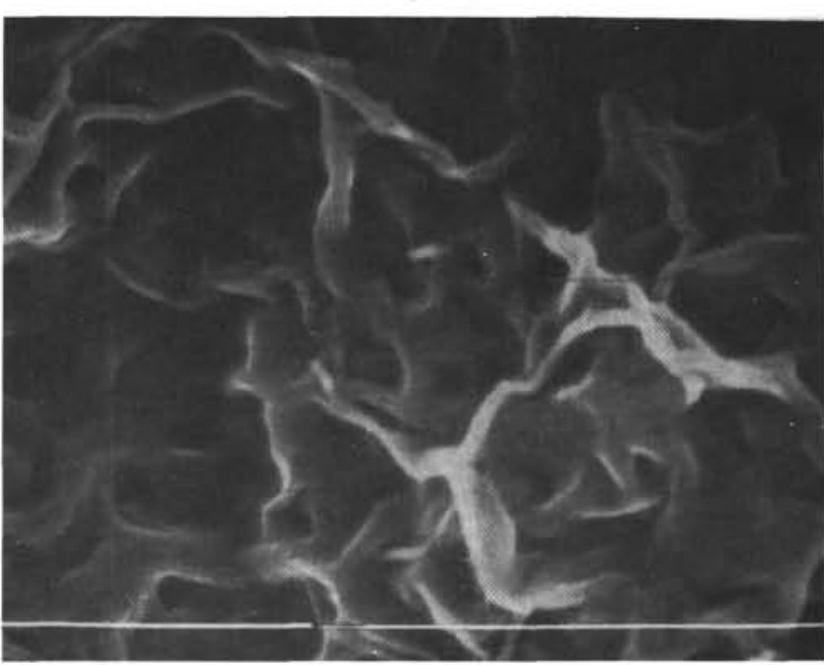

2

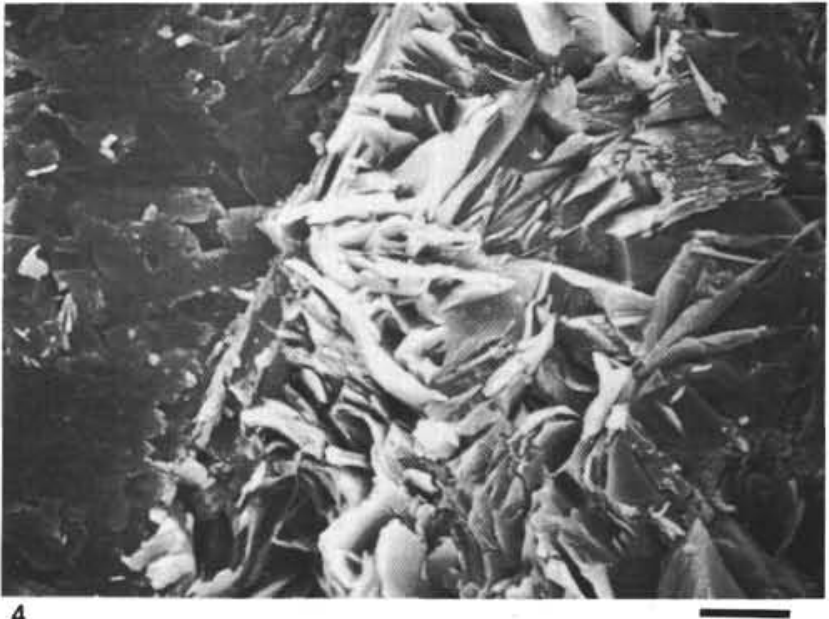

tites or mixed-layer compositions. Scale bar on right side of micrograph $=0.1 \mathrm{~mm}$.

Figure 3. Sample 453-49-2, 137-138 cm, Piece \#19. Red iron-rich clays coating plagioclase and $\mathrm{K}$-feldspar next to metabasalt fragment. EDAX qualitative analysis gave principal peaks for $\mathrm{K}, \mathrm{Fe}$, $\mathrm{Si}$, and $\mathrm{Al}$ on the clay minerals. Small scale bar on micrograph $=$ $0.1 \mathrm{~mm}$.

Figure 4. Sample 453-57-2, 64-67 cm, Piece \#7. Compactly arranged chlorite identified by XRD on separate chip from same sample. EDAX qualititative analysis gave principal peaks for $\mathrm{Al}, \mathrm{Si}, \mathrm{Fe}$, and $\mathrm{Mg}$ (the last only in particular orientations) but not $\mathrm{K}$. The small scale bar below the micrograph $=0.1 \mathrm{~mm}$. 